\title{
Seasonal variations of water-soluble organic carbon, dicarboxylic acids, ketocarboxylic acids, and $\alpha$-dicarbonyls in Central Himalayan aerosols
}

\author{
P. Hegde ${ }^{1,2}$ and K. Kawamura ${ }^{1}$ \\ ${ }^{1}$ Institute of Low Temperature Science, Hokkaido University, Sapporo, Japan \\ ${ }^{2}$ Space Physics Laboratory, Vikram Sarabhai Space Centre, Trivandrum, India \\ Correspondence to: P. Hegde (hegdeprashant@yahoo.com)
}

Received: 29 October 2011 - Published in Atmos. Chem. Phys. Discuss.: 11 January 2012

Revised: 21 June 2012 - Accepted: 8 July 2012 - Published: 26 July 2012

\begin{abstract}
Aerosol samples were collected from a high elevation mountain site (Nainital, India; $1958 \mathrm{~m}$ a.s.l.) in the central Himalayas, a location that provides an isolated platform above the planetary boundary layer to better understand the composition of the remote continental troposphere. The samples were analyzed for water-soluble dicarboxylic acids $\left(\mathrm{C}_{2}-\mathrm{C}_{12}\right)$ and related compounds (ketocarboxylic acids and $\alpha$-dicarbonyls), as well as organic carbon, elemental carbon and water soluble organic carbon. The contributions of total dicarboxylic acids to total aerosol carbon during wintertime were $1.7 \%$ and $1.8 \%$, for day and night, respectively whereas they were significantly smaller during summer. Molecular distributions of diacids revealed that oxalic $\left(\mathrm{C}_{2}\right)$ acid was the most abundant species followed by succinic $\left(\mathrm{C}_{4}\right)$ and malonic $\left(\mathrm{C}_{3}\right)$ acids. The average concentrations of total diacids $\left(433 \pm 108 \mathrm{ng} \mathrm{m}^{-3}\right)$, ketoacids $\left(48 \pm 23 \mathrm{ng} \mathrm{m}^{-3}\right)$, and $\alpha$-dicarbonyls $\left(9 \pm 4 \mathrm{ng} \mathrm{m}^{-3}\right)$ were similar to those from large Asian cities such as Tokyo, Beijing and Hong Kong. During summer most of the organic species were several times more abundant than in winter. Phthalic acid, which originates from oxidation of polycyclic aromatic hydrocarbons such as naphthalene, was found to be 7 times higher in summer than winter. This feature has not been reported before in atmospheric aerosols. Based on molecular distributions and air mass backward trajectories, we conclude that dicarboxylic acids and related compounds in Himalayan aerosols are derived from anthropogenic activities in the highly populated Indo-Gangetic plain areas.
\end{abstract}

\section{Introduction}

Understanding the physical and chemical properties of background aerosols is important in order to determine the source regions, elucidate the mechanism of long-range transport of anthropogenic pollutants and validate both regional and global atmospheric models. The Indian Ocean Experiment (INDOEX) was an international, multiplatform field campaign to assess the climatic and chemical influence of anthropogenic aerosols toward the Indian Ocean (Satheesh and Ramanathan, 2000). From the INDOEX campaign it was established that, during winter, this region would be covered by anthropogenic aerosols carrying sulphate, nitrate, organics, soot and fly ash via long-range transport of air pollution from South and Southeast Asia (Lelieveld et al., 2001). Remote areas of the world were once thought to be less influenced by human atmospheric perturbation, and hence they could provide an opportunity to evaluate the natural background levels of chemical species as well as the effect of anthropogenic pollutants on global atmospheric chemistry (Lee et al., 2003).

The Himalayan Mountain range is located in a remote area of the Asian continent. During the last three decades, chemical studies of aerosols and snow in the Himalayan region have become of great interest in order to evaluate the impact of anthropogenic pollution over the high elevation mountain regions. Several studies have been reported from the northern slope of the Himalayas (Mayewski et al., 1983; Wake et al., 1994; Shrestha et al., 1997; Shrestha et al., 2000; Shrestha et al., 2002) and also from lower elevations in middle Himalayan region (Shrestha et al., 2010). Wake et al. (1994) 
studied aerosol samples collected from the southern slopes of the Himalayas to the northern margin of the Tibetan Plateau and reported high concentrations of organic compounds. The influence of anthropogenic pollutants over the Himalayan region originating from Indian subcontinent has been debated in recent years (Gautam et al., 2010). Recently, Decesari et al. (2010) reported the orographic transport of carbonaceous and sulphate aerosols upslope the Himalayas, showing that valley wind circulation brings anthropogenic aerosols into the Asian upper troposphere (>5000 m a.s.l.). Similar observations for black carbon (BC) aerosols were made by Marinoni et al. (2010) over the Nepal Climate ObservatoryPyramid, a permanent high-altitude research station located in the Khumbu valley (5079 m a.s.l.) below Mt. Everest. All these studies revealed that the remote mountainous region and, to some extent, the middle-upper troposphere are polluted by human activities.

Studies of organic aerosols at the molecular level are limited because of their complexity and thus difficulties in their measurements. Previous studies, however, demonstrated that water-soluble organic compounds account for a significant fraction (28-77\%) of organic aerosol mass (Saxena et al., 1995; Kawamura et al., 2003). Among the water-soluble organic compounds, low molecular weight dicarboxylic acids with a predominance of oxalic acid have been found as an important fraction of organic aerosols in the continental and marine atmosphere (Kawamura and Ikushima 1993; Kawamura and Sakaguchi 1999; Kawamura et al., 2004). Due to their hygroscopic property, diacids play an important role in the global radiative balance (Saxena et al., 1995; Facchini et al., 1999; Kerminen, 2001). These species are directly emitted to the atmosphere from natural and anthropogenic sources or secondarily produced by atmospheric chemical reactions (Kawamura and Kaplan, 1987; Schauer et al., 1999; Simoneit et al., 2005). However, data about diacids are limited in remote South Asia including the Himalayan region. On average, over the entire Indian subcontinent, chemical mass balance studies based on the ISRO-GBP campaign (Indian Space Research Organization - Geosphere Biosphere Programme) have estimated the particulate organic matter contribution to be about $20-30 \%$ of the total aerosol mass load (George et al., 2008).

Over south Asia, the Indo-Gangetic plain is recognized as an especially densely populated region and thus as a potentially strong source region of anthropogenic aerosols (Tripathi et al., 2005; Ram et al., 2010). The Himalaya Mountain range exists over the northern part of these highly populated and industrialized areas. Due to its high elevation, the Himalayan range acts as a boundary limiting the northern extent of the Indian summer monsoon, and therefore observations at a high altitude location, Nainital $\left(29.4^{\circ} \mathrm{N} ; 79.5^{\circ} \mathrm{E}\right.$, $1958 \mathrm{~m}$ a.s.1.), would provide information about emissions over the Indian subcontinent. Our observation site is located at the highest mountain top (over the Kumaon region) and about $2 \mathrm{~km}$ from Nainital City (population $\sim 0.5$ million). The site is devoid of any major local pollution sources and is generally free from snow coverage during most of the time. The north and northeast sides of study area are characterized by sharply peaking topography of the Himalayan Mountain range, whereas on the south-western side plains with very low elevation ( $<500 \mathrm{~m}$ a.s.l.) merge into the densely populated Ganga basin.

To better understand the atmospheric chemistry of organic aerosols in the Himalayan range, we collected aerosol samples at Nainital at the foothills of the central Himalayas and performed measurements of organic carbon (OC), elemental carbon (EC), water soluble organic carbon (WSOC), dicarboxylic acids and related compounds. Here, we report molecular distributions of water-soluble organic compounds that would provide unique information about their sources and formation pathways. Multiple sources of organic aerosols are also discussed based on air mass backward trajectories and regional meteorology.

\section{Experimental}

\subsection{Meteorology}

The climate of this part of the Asian continent is mainly controlled by air masses originating from the Arctic (western disturbances), continental air masses from central Asia, and maritime air masses from the Pacific and Indian Oceans (Indian summer monsoon). The Himalayan Mountain range plays a key role in the regional climate. It blocks the midlatitudinal westerlies and splits the westerly jet into north and the south pathways over the Tibetan Plateau. During winter months, western disturbances (synoptic scale low pressure weather systems) frequently occur over the northwestern part of India. These cold air masses originate over the Mediterranean Sea and Atlantic Ocean and bring high moisture and snowfall over the high altitude locations.

A common method for the identification of the origin and the pathway of air masses is to calculate backward trajectories. Fig. 1 gives the National Oceanic and Atmospheric Administration (NOAA) Hybrid Single Particle Lagrangian Trajectory (HYSPLIT) model ( $24 \mathrm{~h}$ interval; FNL Meteorological Data: Draxler and Rolph, 2010; Rolph, 2010) seven day backward trajectories illustrating typical air-mass flows from different parts of the Indian subcontinent to the study area (Nainital) at three different heights $(500 \mathrm{~m}, 1000 \mathrm{~m}$ and $1500 \mathrm{~m}$ above ground level). It is important to note that air masses at this site do not arrive from the north and northeastern sector in any season because of high mountains in that direction. From the air mass trajectories it is clear that during mid September the winds circulate mostly over the Northern Indian region and change gradually to westerly by early December, while during the first week of March air masses remain westerly/southwesterly. The trajectory patterns change 
Winter 2006

NOAA HYSPUIT MODEL

Backward trajectories ending at 0000 UTC 10 Sep 06 CDC1 Meteorological Data

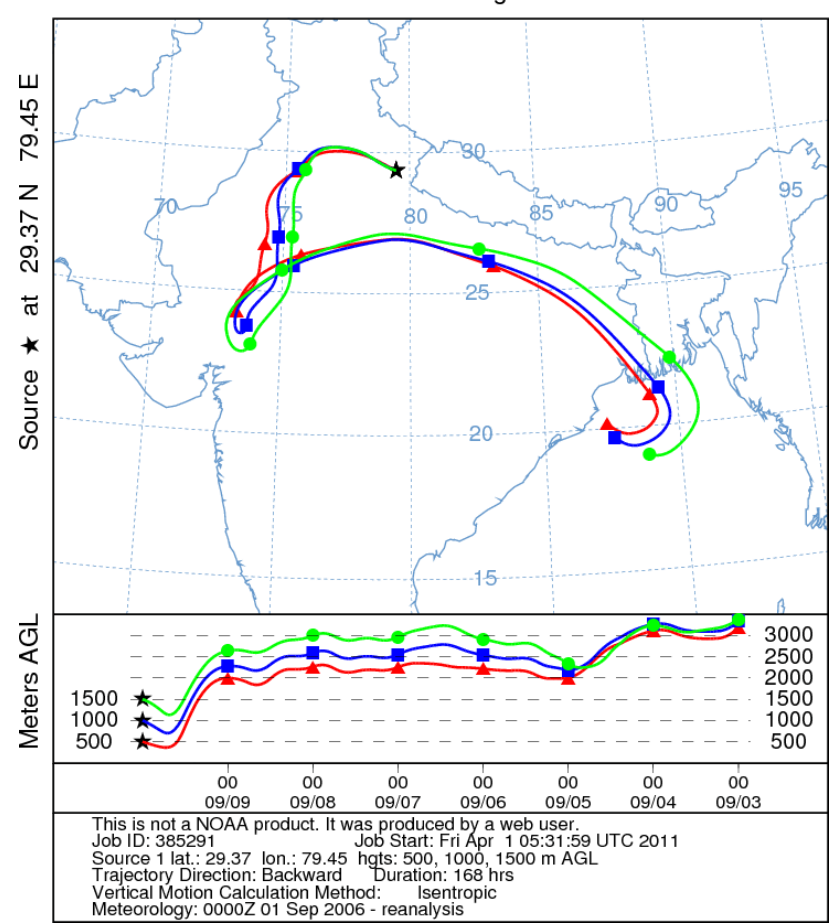

Summer 2007

NOAA HYSPLIT MODEL

Backward trajectories ending at 0000 UTC 01 Mar 07 CDC1 Meteorological Data

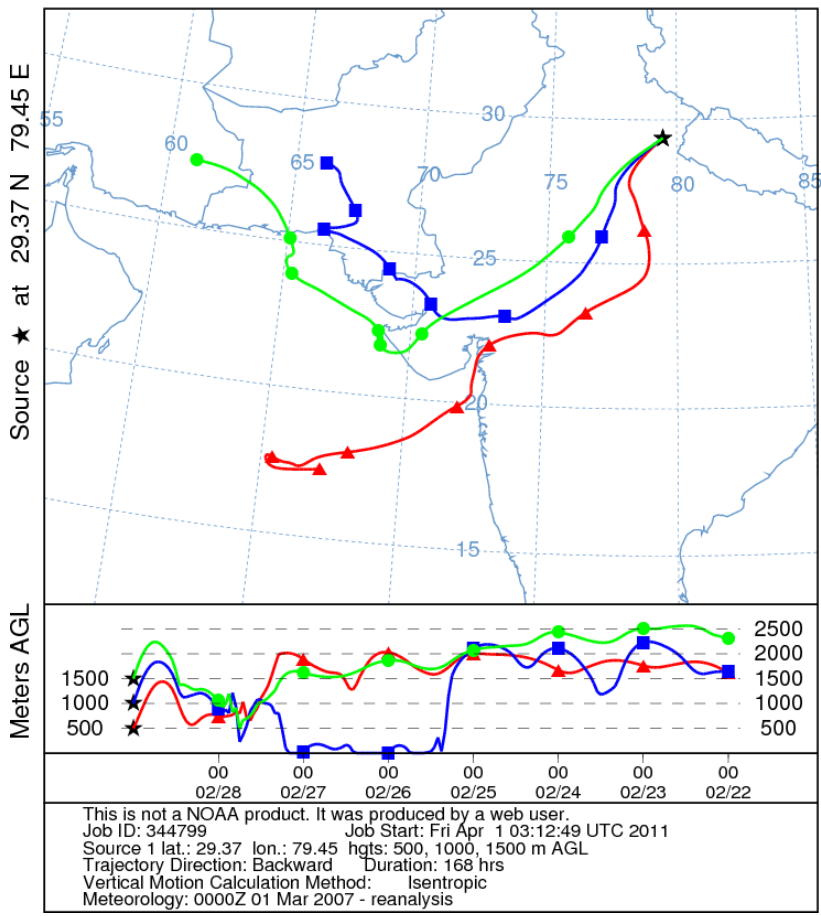

NOAA HYSPLIT MODEL

Backward trajectories ending at 0000 UTC 01 Dec 06 CDC1 Meteorological Data

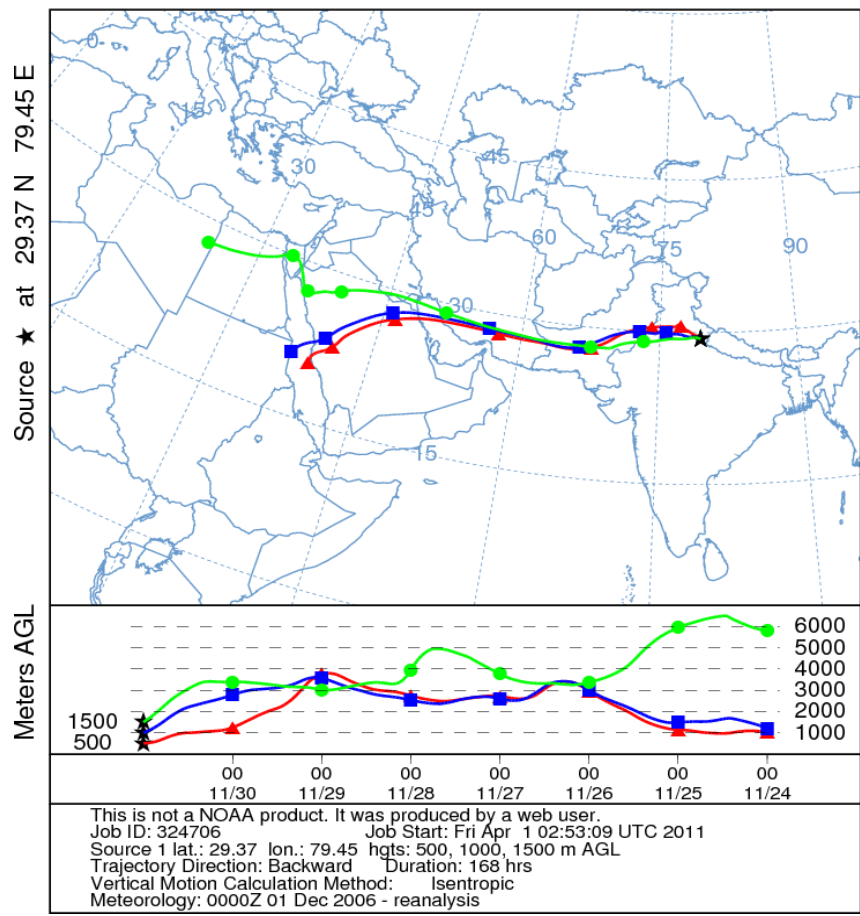

NOAA HYSPLIT MODEL

Backward trajectories ending at 0000 UTC 10 Jun 07 CDC1 Meteorological Data

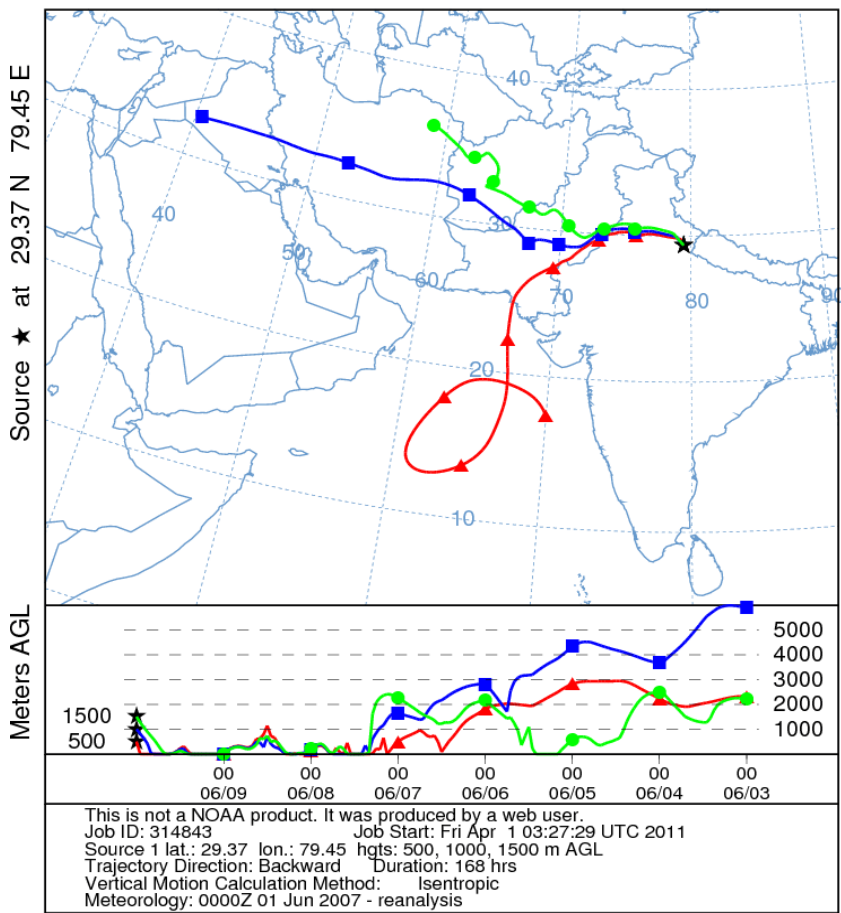

Fig. 1. Air mass backward trajectory cluster during the study period reaching Nainital (star symbol) to illustrate the long-range transport. 
(a) Temperature in degree centigrade

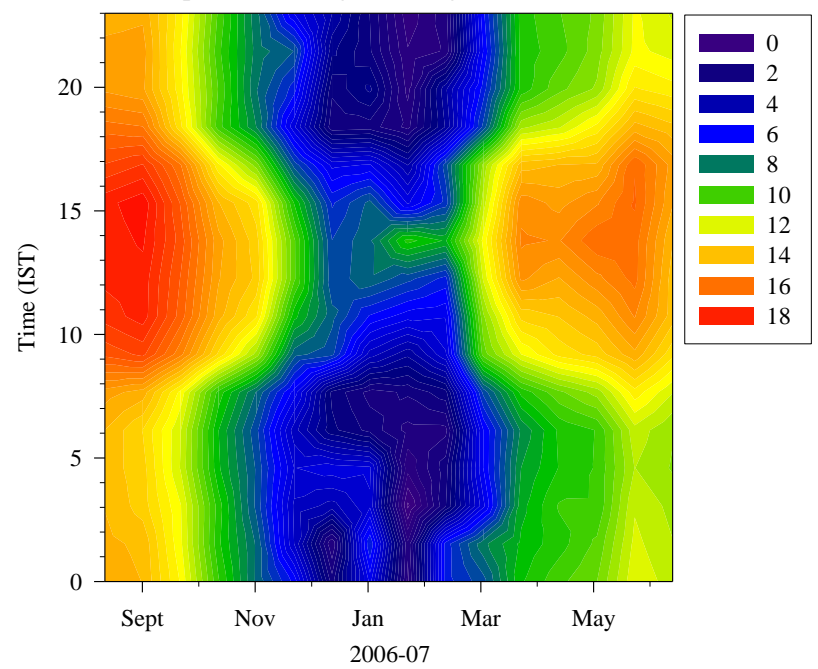

(b) Relative humidity (\%)

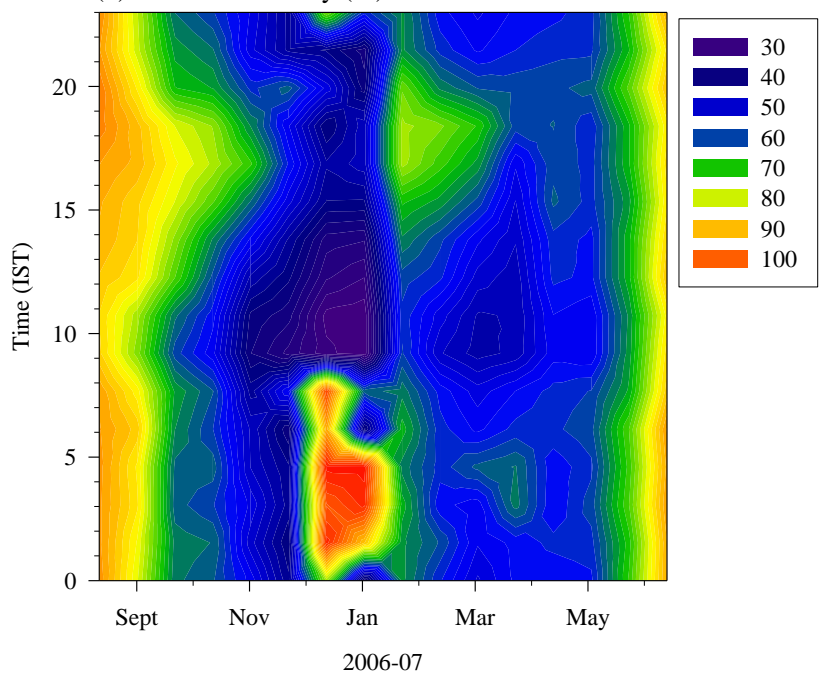

Fig. 2. Monthly mean diurnal and seasonal variation of (a) ambient air temperature (in degree centigrade) and (b) relative humidity (\%) measured over the observational site during the study period.

again from southwesterly to westerly/northwesterly during mid June. Such shifts in wind pattern are observed every year.

A similar trend of change in wind direction was also noticed from surface observation by an automated weather station (AWS). Standard meteorological sensors (AWS; Dynalab, India; Campbell Scientific Inc., Canada) were used for observations of meteorological parameters. The daily mean diurnal and seasonal variation for temperature and relative humidity are shown in Fig. $2 \mathrm{a}$ and $\mathrm{b}$, respectively. By the end of September temperature gradually started to decrease from maximum of $16^{\circ} \mathrm{C}$ to minimum of $0{ }^{\circ} \mathrm{C}$ by December and January. With beginning of summer months, temperatures raised to a daytime maximum of $18^{\circ} \mathrm{C}$. Significant diurnal variation in temperature is noticed. Higher temperatures are recorded during afternoon hours and are more promi- nent during summer months. Contemporaneous with temperature, relative humidity also shows a seasonal trend. As the monsoon rains withdraw (during September), the relative humidity gradually decreases down to $40 \%$. December months retain moderate to high relative humidity $(50 \%$ to $90 \%$ ). March, April and May months are relatively dry $(<50 \%)$. The mean wind speed recorded was $<4 \mathrm{~m} \mathrm{~s}^{-1}$ during winter months, whereas during summer months it almost doubled (figure not shown). The topography around the observation site and the general meteorology prevailing during different seasons has been discussed in detail by Sagar et al. (2004) and Pant et al. (2006).

\subsection{Aerosol sampling}

Aerosol samples were collected from single-stage high volume sampler (Model GH2000 of Graseby Anderson, USA) using quartz fiber filters (Whatman QMA4) of $9 \mathrm{~cm}$ in diameter. Sampling was carried out on the terrace of a building (20 $\mathrm{m}$ above ground level) from September 2006 to January 2007 and March to June 2007 (hereafter referred as winter and summer seasons, respectively). During winter season, the samples were collected for daytime ( 9 a.m. to 6 p.m., $N=9$ ) and nighttime ( 7 p.m. to 8 a.m., $N=9$ ), whereas during summer the sampling hours were shorter; daytime (10 a.m. to 1 p.m., $N=11$ ) and nighttime (8 p.m. to 11 p.m., $N=10$ ). Two filters were collected in a day representing daytime and nighttime samples. During winter season, sampling frequency was 15 days, whereas during summer period the samples were collected more often; ( $\sim 10$ days). The flow rate of the sampler was set at $400 \mathrm{~L} \mathrm{~min}^{-1}$. Field blanks were collected by putting another set of filters in the sampler for the same duration without operating the sampler. Before sampling, filter papers were pre-heated at $400^{\circ} \mathrm{C}$ in an electric furnace using aluminum foil. The filters were tare-weighed using a microbalance (Mettler Model AT 20 with a sensitivity of $\pm 2 \mu \mathrm{g}$ ) and preserved $\sim-4{ }^{\circ} \mathrm{C}$ in a freezer until further chemical analysis.

\subsection{Chemical analysis}

Concentrations of total suspended particulate matter (TSPM) in air were calculated gravimetrically on the basis of volume of air sampled and the weight of the aerosol particles. The filter papers were conditioned in a desiccator for about $48 \mathrm{~h}$ before and after sampling. To measure water-soluble organic carbon (WSOC), $1.4 \mathrm{~cm}$ in diameter filter disc was extracted with organic-free Milli-Q water using ultrasonication for $15 \mathrm{~min}$. The water extracts were subsequently passed through a syringe filter (Millex-GV, $0.22 \mu \mathrm{m}$, Millipore), and WSOC was measured using a total organic carbon (TOC) analyzer (Shimadzu, TOC- $\mathrm{V}_{\mathrm{CSH}}$ ) equipped with a catalytic oxidation column/nondispersive infrared detector (Aggarwal and Kawamura, 2008). The sample was measured three times and the average value was used in this study. Before the sample 
analysis, external calibration was performed using potassium hydrogen phthalate. The analytical error of the measurement was $15 \%$ with a detection limit of $0.1 \mu \mathrm{g} \mathrm{C} \mathrm{m}{ }^{-3}$.

$\mathrm{OC}$ and $\mathrm{EC}$ in the samples were measured using a OC/EC analyzer (Sunset Laboratory Inc., Portland, OR, USA) following the Interagency Monitoring of Protected Visual Environments (IMPROVE-B) thermal protocol (Agarwal et al., 2010). A filter punch (area $1.5 \mathrm{~cm}^{2}$ ) of the sample was placed in a quartz tube which was placed inside the thermal desorption chamber of the analyzer. OC concentrations were determined in helium atmosphere at $~ 120,250,450$ and $550^{\circ} \mathrm{C}$. Subsequently, oxygen $(2 \%)$ was introduced and EC concentrations were determined at temperatures from $~ 550$ to $900^{\circ} \mathrm{C}$. The pyrolytic conversion of OC to EC was monitored and corrected by using a He-Ne laser. The calibration of the instrument was performed using a known amount of sucrose at 4 different concentrations (20, 40, 60 and $80 \mu \mathrm{gC})$. The detection limits of OC and EC, which are defined as three times the standard deviation of field blanks, were 0.26 and $0.01 \mu \mathrm{gCm}^{-3}$, respectively. Conversely, these values are lower than the detection limit of $0.5 \mu \mathrm{gCm}{ }^{-3}$ provided by the manufacturer.

Samples were analyzed for diacids, ketoacids, and $\alpha$ dicarbonyls using a method reported previously (Kawamura and Ikushima, 1993; Kawamura, 1993) with a pH adjustment of the water extracts to $\mathrm{pH}=8.5-9.0$ with $0.1 \mathrm{M} \mathrm{KOH}$. Briefly, a part of the quartz-filter was cut into pieces and extracted with ultrapure Milli-Q water $(10 \mathrm{~mL} \times 3)$ using ultrasonication for about $10 \mathrm{~min}$. After filtration with quartz wool, the filtrate was transferred to a $50 \mathrm{ml}$ flask and concentrated to almost dryness using a rotary evaporator under vacuum. The extracts were then converted to dibutyl esters and/or dibutoxy acetals with $14 \% \mathrm{BF}_{3} / \mathrm{n}$-butanol at $100^{\circ} \mathrm{C}$. The butyl esters and acetals were extracted with n-hexane. The derivatised fractions were analyzed using a capillary HP 6890 gas chromatograph (GC). Peak identification was performed by GC retention times of authentic standards and confirmed by mass spectral examination using a GC-mass spectrometer (GC-MS) system.

We spiked free diacid standards on precombusted quartz fiber filters in order to evaluate the recovery. They were extracted and analyzed the same as real samples. The recoveries of authentic standards were $92 \%$ for oxalic acid and greater than $95 \%$ for malonic, succinic, and adipic acids. With $\mathrm{pH}$ adjustment, the recovery of oxalic acid was improved. The variations due to analytical errors for duplicate analysis of the filter sample were within $10 \%$ for all the measured major species. Field and laboratory blanks showed minute peaks for oxalic, phthalic, and glyoxylic acids. Nevertheless, their amounts were less than $2 \%$ of the actual samples. Concentrations of all diacids and related compounds reported here are corrected for field blanks, but not for recoveries.

\section{Results and discussion}

\subsection{Total suspended particulate matter}

Figure 3 shows the temporal variations of total suspended particulate matter (TSPM) along with the concentrations of total diacids, total ketoacids, and total $\alpha$-dicarbonyls in the aerosol samples over the study area. Concentrations of TSPM during winter period were on average $81 \pm 19 \mu \mathrm{g}$ $\mathrm{m}^{-3}$ and $59 \pm 21 \mu \mathrm{g} \mathrm{m}^{-3}$ for day and night, respectively. During summer the concentrations were moderately higher; $92 \pm 30 \mu \mathrm{g} \mathrm{m}^{-3}$ in daytime and $70 \pm 16 \mu \mathrm{g} \mathrm{m}^{-3}$ in nighttime. On average, nighttime mass concentrations were marginally lower than daytime concentrations by $\sim 30 \%$. This day- and night-time difference as well as seasonal variations in aerosol mass loading seem to be closely associated with the vertical movement of atmospheric boundary layer followed by long-range transport. Generally, during winter periods the solar insolation over the region weakens, therefore the temperature drops to minimum especially during night. The atmospheric boundary layer (stable/nocturnal boundary layer) stays far below the observation site and thus the air over the location may represent the free tropospheric features. After sunrise, thermal structure starts to develop as the land warms. The resulting convective motions become stronger at the valley region, initiating the uplifting of the inversion layer formed by low level ground-based capping along with the vertical transport of pollutants. As the day advances, the boundary layer height increases, thereby capping inversion breaks, and pollutants from the valley region (including Indo Gangetic plains) are readily transported to higher levels. During summer this feature is often observed as reported by Sagar et al. (2004), but for a longer duration. Further, Dumka et al. (2010) have observed that, the upslope winds resulting from the radiative heating of mountain surfaces along valley winds during afternoon hours may transport aerosol particles from adjacent plains to the sampling site, whereas the down slope winds due to the radiative cooling of the mountain surfaces at night create the opposite effect.

\subsection{OC, EC, WSOC and WIOC}

The concentrations of EC, OC, TC (total carbon) and WSOC mass concentrations in Nainital aerosol samples are given in Table 1. Overall, three carbonaceous components (OC, EC and WSOC) generally correlate well each other, showing minima during winter and maxima during summer ( 2 times larger). As compared to daytime averages, nighttime concentrations were significantly lower except for EC during winter. The observed concentrations of OC $\left(6.2 \mu \mathrm{g} \mathrm{m}^{-3}\right.$ and $16.5 \mu \mathrm{g} \mathrm{m}^{-3}$ for winter and summer, respectively) as well as EC $\left(1.4 \mu \mathrm{g} \mathrm{m}^{-3}\right.$ and $4.3 \mu \mathrm{g} \mathrm{m}^{-3}$ for winter and summer, respectively) over Nainital were much lower than the annual average concentrations observed in Beijing $\left(22.4 \mu \mathrm{g} \mathrm{m}^{-3}\right.$ for OC and $7.88 \mu \mathrm{g} \mathrm{m}^{-3}$ for EC) (Favez et al., 2008). Conversely, 
Table 1. Concentrations $\left(\mathrm{ng} \mathrm{m}^{-3}\right)$ of dicarboxylic acids, ketocarboxylic acids, and $\alpha$-dicarbonyls and concentrations $\left(\mu \mathrm{g} \mathrm{m}^{-3}\right.$ ) of elemental carbon (EC), organic carbon (OC), total carbon (TC) and water soluble organic carbon (WSOC) in Himalayan aerosols over Nainital, India.

\begin{tabular}{|c|c|c|c|c|c|c|c|c|}
\hline \multirow[b]{3}{*}{ Compounds } & \multicolumn{4}{|c|}{ Winter } & \multicolumn{4}{|c|}{ Summer } \\
\hline & \multicolumn{2}{|c|}{ Day $(N=9)$} & \multicolumn{2}{|c|}{ Night $(N=9)$} & \multicolumn{2}{|c|}{ Day $(N=11)$} & \multicolumn{2}{|c|}{ Night $(N=10)$} \\
\hline & Range & Ave. \pm SD & Range & Ave. \pm SD & Range & Ave. \pm SD & Range & Ave. \pm SD \\
\hline \multicolumn{9}{|c|}{ Dicarboxylic acids } \\
\hline Oxalic $\left(\mathrm{C}_{2}\right)$ & $285-492$ & $393 \pm 78$ & $213-474$ & $313 \pm 88$ & $138-425$ & $242 \pm 90$ & $106-389$ & $189 \pm 92$ \\
\hline Malonic $\left(\mathrm{C}_{3}\right)$ & $7.9-22$ & $15 \pm 4.3$ & $5.8-36$ & $18 \pm 10$ & $16-77$ & $34 \pm 17$ & $13-52$ & $26 \pm 15$ \\
\hline Succinic $\left(C_{4}\right)$ & $9.5-21$ & $17 \pm 3.9$ & $8.1-40$ & $19 \pm 11$ & $19-86$ & $40 \pm 19$ & $15-53$ & $29 \pm 14$ \\
\hline Glutaric $\left(\mathrm{C}_{5}\right)$ & $2.3-5.5$ & $3.9 \pm 1.0$ & $2.2-6.4$ & $3.8 \pm 1.7$ & $5.0-16.5$ & $8.9 \pm 3.4$ & $3.9-9.8$ & $6.0 \pm 2.2$ \\
\hline Adipic $\left(\mathrm{C}_{6}\right)$ & $2.7-8.2$ & $4.5 \pm 1.6$ & $1.9-17$ & $6.4 \pm 5.5$ & $5.2-17.3$ & $9.6 \pm 3.5$ & $3.5-7.8$ & $6.0 \pm 1.5$ \\
\hline Pimelic $\left(\mathrm{C}_{7}\right)$ & $0.7-2.5$ & $1.6 \pm 0.5$ & $0.4-2.1$ & $1.3 \pm 0.6$ & $0.5-7.2$ & $3.5 \pm 2.4$ & $0.6-5.6$ & $2.3 \pm 1.5$ \\
\hline Suberic $\left(\mathrm{C}_{8}\right)$ & $0.2-0.5$ & $0.3 \pm 0.1$ & $0.1-0.6$ & $0.3 \pm 0.2$ & $0.2-2.3$ & $0.9 \pm 0.6$ & $0.3-3.4$ & $0.8 \pm 0.9$ \\
\hline Azelaic $\left(\mathrm{C}_{9}\right)$ & $2.9-5.5$ & $4.3 \pm 0.8$ & $2.3-6.1$ & $3.8 \pm 1.3$ & $3.4-35$ & $17 \pm 11$ & $3.8-27$ & $14 \pm 8.2$ \\
\hline $\operatorname{Sebacic}\left(\mathrm{C}_{10}\right)$ & $0.5-0.9$ & $0.6 \pm 0.1$ & $0.3-0.8$ & $0.5 \pm 0.2$ & $0.2-3.6$ & $1.5 \pm 1$ & $0.3-4.6$ & $2.2 \pm 1.5$ \\
\hline Undecanedioic $\left(\mathrm{C}_{11}\right)$ & $0.6-2.5$ & $1.2 \pm 0.7$ & $0.4-3.0$ & $1.3 \pm 0.8$ & $0.2-5.1$ & $1.9 \pm 1.6$ & $0.4-4.6$ & $1.6 \pm 1.5$ \\
\hline Dodecanedioic $\left(\mathrm{C}_{12}\right)$ & $0.1-0.8$ & $0.3 \pm 0.2$ & $0.1-0.4$ & $0.2 \pm 0.1$ & $0.1-2.1$ & $0.9 \pm 0.6$ & $0.2-1.9$ & $1.1 \pm 0.7$ \\
\hline Methylmalonic $\left(i \mathrm{C}_{4}\right)$ & $0.3-1.4$ & $0.5 \pm 0.4$ & $0.1-1.1$ & $0.5 \pm 0.3$ & $0.5-7.4$ & $2.0 \pm 2.0$ & $0.1-2.1$ & $1.2 \pm 0.6$ \\
\hline Methylsuccinic $\left(i \mathrm{C}_{5}\right)$ & $0.7-2.8$ & $1.8 \pm 0.6$ & $0.8-5.6$ & $2.2 \pm 1.7$ & $2.0-8.5$ & $3.6 \pm 2.2$ & $1.1-5.9$ & $2.8 \pm 1.7$ \\
\hline Methylglutaric $\left(i \mathrm{C}_{6}\right)$ & $0.2-0.7$ & $0.4 \pm 0.2$ & $0.1-0.8$ & $0.4 \pm 0.2$ & $0.2-4.5$ & $1.5 \pm 1.2$ & $0.7-4.1$ & $1.4 \pm 1.0$ \\
\hline Maleic (M) & $0.04-1.3$ & $0.7 \pm 0.4$ & $0.4-5.7$ & $1.6 \pm 1.6$ & $1.0-7.2$ & $4.0 \pm 1.8$ & $0.2-3.9$ & $2.7 \pm 1.0$ \\
\hline Fumaric $(\mathrm{F})$ & $0.6-0.9$ & $0.8 \pm 0.1$ & $0.6-1.8$ & $1.0 \pm 0.4$ & $1.0-6.4$ & $4.0 \pm 1.5$ & $1.0-11$ & $3.5 \pm 3.2$ \\
\hline Methylmaleic (mM) & $0.4-0.9$ & $0.7 \pm 0.2$ & $0.3-3.9$ & $1.3 \pm 1.1$ & $0.7-4.4$ & $2.3 \pm 1.4$ & $0.8-14$ & $3.2 \pm 3.9$ \\
\hline Phthalic $(\mathrm{Ph})$ & $8.9-17$ & $12 \pm 2.8$ & $5.8-23$ & $13 \pm 5.6$ & $26-182$ & $88 \pm 55$ & $21-159$ & $75 \pm 54$ \\
\hline Isophthalic (iPh) & $1.3-2.8$ & $1.7 \pm 0.5$ & $0.2-3.0$ & $1.6 \pm 0.9$ & $1.3-5.5$ & $3.4 \pm 1.6$ & $0.4-5.6$ & $3.1 \pm 1.7$ \\
\hline Terephthalic (tPh) & $1.2-9.8$ & $4.8 \pm 3.3$ & $2.7-8.2$ & $4.8 \pm 1.8$ & $0.7-8.8$ & $3.4 \pm 2.3$ & $1.9-11$ & $4.2 \pm 2.7$ \\
\hline Malic $\left(\mathrm{hC}_{4}\right)$ & $0.02-0.3$ & $0.1 \pm 0.1$ & $0.1-0.4$ & $0.1 \pm 0.1$ & $0.1-4.8$ & $0.8 \pm 1.4$ & $0.1-0.6$ & $0.2 \pm 0.2$ \\
\hline Oxomalonic $\left(\mathrm{kC}_{3}\right)$ & $2.7-8.7$ & $5.4 \pm 2.3$ & $2.5-8.2$ & $5.0 \pm 1.8$ & $1.4-7.8$ & $4.6 \pm 1.9$ & $1.6-7.2$ & $3.5 \pm 1.7$ \\
\hline 4-Oxopimelic $\left(\mathrm{kC}_{7}\right)$ & $0.3-2.8$ & $1.6 \pm 0.8$ & $0.8-2.7$ & $1.4 \pm 0.6$ & $0.8-4.8$ & $2.1 \pm 1.3$ & $0.6-4.0$ & $1.8 \pm 1.1$ \\
\hline Subtotal & $361-591$ & $473 \pm 86$ & $283-569$ & $400 \pm 108$ & $303-729$ & $480 \pm 132$ & $233-592$ & $380 \pm 107$ \\
\hline \multicolumn{9}{|c|}{ Ketocarboxylic acids } \\
\hline Glyoxylic $\left(\omega \mathrm{C}_{2}\right)$ & $7.8-22$ & $13 \pm 5.5$ & $6.1-21$ & $11 \pm 5.1$ & $8.9-37$ & $23 \pm 8.1$ & $8.7-30$ & $16 \pm 6.8$ \\
\hline 3-Oxopropanoic $\left(\omega \mathrm{C}_{3}\right)$ & $1.6-4.4$ & $2.6 \pm 1.0$ & $1.3-4.3$ & $2.3 \pm 1.1$ & $2.1-8.6$ & $4.5 \pm 1.8$ & $1.8-7.2$ & $3.6 \pm 1.7$ \\
\hline 4-Oxobutanoic $\left(\omega \mathrm{C}_{4}\right)$ & $1.7-6.5$ & $3.4 \pm 1.6$ & $1.5-7.4$ & $3.4 \pm 2.0$ & $0.2-7.8$ & $4.4 \pm 2.7$ & $0.3-7.8$ & $4.6 \pm 2.0$ \\
\hline 5-Oxopentanoic $\left(\omega \mathrm{C}_{5}\right)$ & $0.4-1.3$ & $0.8 \pm 0.3$ & $0.4-1.4$ & $0.7 \pm 0.3$ & $0.1-1.8$ & $0.9 \pm 0.6$ & $0.2-1.6$ & $0.9 \pm 0.4$ \\
\hline 7-Oxoheptanoic $\left(\omega \mathrm{C}_{7}\right)$ & $2.3-7.5$ & $4.1 \pm 1.6$ & $2.2-7.2$ & $3.6 \pm 1.6$ & $1.8-6.5$ & $3.4 \pm 1.5$ & $1.5-4.4$ & $2.5 \pm 1.0$ \\
\hline 8-Oxooctanoic $\left(\omega \mathrm{C}_{8}\right)$ & $4.3-15$ & $8.6 \pm 4.3$ & $3.4-13$ & $6.5 \pm 3.2$ & $0.1-5.0$ & $2.6 \pm 1.9$ & $0.1-4.1$ & $2.1 \pm 1.3$ \\
\hline 9-Oxononanoic $\left(\omega \mathrm{C}_{9}\right)$ & $0.5-8.6$ & $2.9 \pm 2.3$ & $0.8-9.9$ & $4.0 \pm 2.9$ & $0.7-154$ & $24 \pm 45$ & $0.4-33$ & $11 \pm 13$ \\
\hline Pyruvic (Pyr) & $2.9-5.1$ & $3.7 \pm 0.8$ & $2.1-6.9$ & $3.7 \pm 1.7$ & $2.9-15$ & $9.6 \pm 4.0$ & $1.4-10$ & $6.4 \pm 2.9$ \\
\hline Subtotal & $28-62$ & $39 \pm 12$ & $20-57$ & $35 \pm 14$ & $26-195$ & $72 \pm 46$ & $22-73$ & $47 \pm 18$ \\
\hline \multicolumn{9}{|c|}{$\alpha$-Dicarbonyls } \\
\hline Glyoxal (Gly) & $1.5-4.1$ & $2.6 \pm 1.0$ & $1.3-3.8$ & $2.3 \pm 1.0$ & $4.2-21$ & $10 \pm 5.5$ & $1.6-23$ & $9.4 \pm 6.6$ \\
\hline Methylglyoxal (MeGly) & $0.9-2.9$ & $1.7 \pm 0.6$ & $1.0-2.9$ & $1.7 \pm 0.7$ & $0.2-8.0$ & $2.7 \pm 2.7$ & $0.3-5.8$ & $3.7 \pm 1.7$ \\
\hline Subtotal & $2.7-6.6$ & $4.3 \pm 1.4$ & $2.2-6.3$ & $4.0 \pm 1.5$ & $5.1-22$ & $13 \pm 6.7$ & $3.3-27$ & $13 \pm 7.0$ \\
\hline $\mathrm{EC}\left(\mu \mathrm{gC} \mathrm{m}{ }^{-3}\right)$ & $0.6-2.4$ & $1.3 \pm 0.6$ & $0.8-2.2$ & $1.4 \pm 0.5$ & $0.7-11$ & $4.6 \pm 2.8$ & $1.1-8.0$ & $3.9 \pm 2.2$ \\
\hline $\mathrm{OC}\left(\mu \mathrm{gC} \mathrm{m}{ }^{-3}\right)$ & $4.8-9.9$ & $6.9 \pm 1.9$ & $3.3-8.8$ & $5.4 \pm 1.8$ & $7.5-35$ & $17 \pm 8.7$ & $6.2-31$ & $16 \pm 6.8$ \\
\hline $\mathrm{TC}\left(\mu \mathrm{gC} \mathrm{m}{ }^{-3}\right)$ & $5.4-12$ & $8.2 \pm 2.5$ & $4.5-10$ & $6.8 \pm 2.1$ & $11-46$ & $22 \pm 11$ & $7.3-39$ & $19 \pm 8.8$ \\
\hline WSOC $\left(\mu \mathrm{gC} \mathrm{m}^{-3}\right)$ & $2.1-5.4$ & $3.4 \pm 1.1$ & $1.5-4.1$ & $2.8 \pm 0.9$ & $2.3-10$ & $5.0 \pm 2.2$ & $2.6-11$ & $4.7 \pm 2.6$ \\
\hline
\end{tabular}




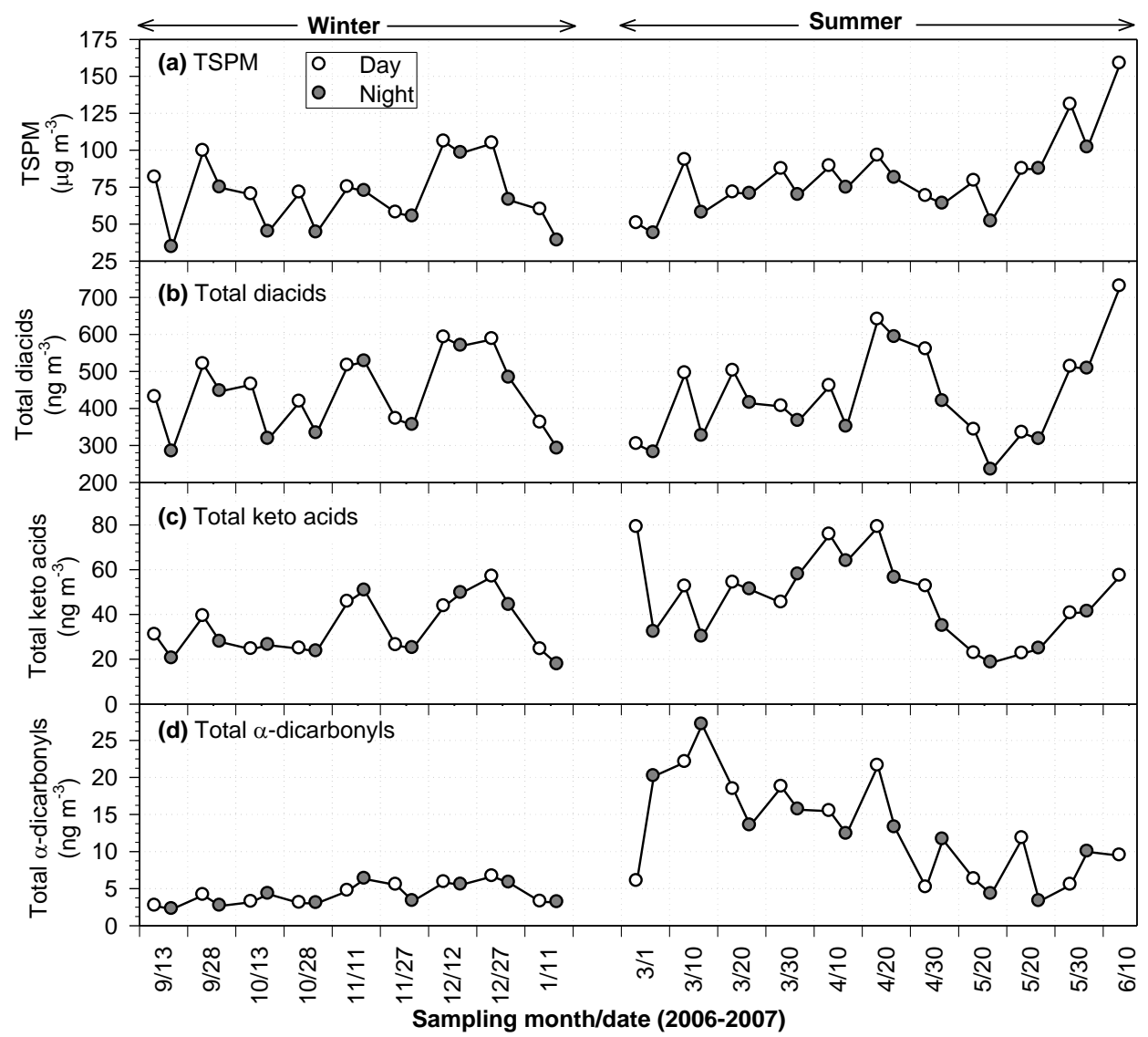

Fig. 3. Temporal variations in total suspended particulate matter (TSPM) along with mass fraction of total diacids, total ketoacids, and total $\alpha$-dicarbonyls in TSPM for aerosol samples collected at Nainital, India.

OC and EC concentrations in Nainital were higher than those observed in other megacities in developed countries such as Belgium $\left(4.12 \mu \mathrm{g} \mathrm{m}^{-3} \mathrm{OC}\right.$ and $\left.1.80 \mu \mathrm{g} \mathrm{m}^{-3} \mathrm{EC}\right)$ and Italy (5.91 $\mathrm{g} \mathrm{m}^{-3}$ OC and $1.44 \mu \mathrm{g} \mathrm{m}^{-3} \mathrm{EC}$ ) (Viana et al., 2007) and in Paris $\left(5.9 \mu \mathrm{g} \mathrm{m}^{-3} \mathrm{OC}\right.$ and $1.7 \mu \mathrm{g} \mathrm{m}^{-3}$ EC) (Favez et al., 2008).

$\mathrm{EC}$ is a product of incomplete combustion of residential coal, motor vehicle fuel, and biomass. OC originates from primary anthropogenic sources and also from formation (secondary OC) by chemical reactions in the atmosphere. Higher OC/EC ratios indicate an influence from biomass-burning sources (as well as biogenic sources), whereas lower ratios are attributable to fossil-fuel combustion. OC levels were considerably higher than EC for all our samples. During wintertime the OC/EC ratios were $5.86 \pm 1.46$ for day and $4.03 \pm 1.27$ for night, whereas during summertime the ratios were slightly lower $(3.77 \pm 1.32$ and $4.43 \pm 1.37)$. As compared to vehicular exhausts, the emissions from residential coal burning for house heating contain more organic pollutants that result in higher OC/EC ratios during winter (Cao et al., 2005). Over rural areas of northwestern India, biomass burning is quite common for house heating and cooking, which apparently releases more organic pollutants compared to fossil fuel emissions.

The OC/EC ratios obtained in this study (annual range 1.91 to 8.29) cover the range known for the vehicular exhaust and biomass burning emissions reported by Saarikoski et al. (2008) for northern European urban environment in Helsinki, Finland. Recently, Sandradewi et al. (2008) observed relatively lower OC/EC ratios for vehicular emission from road traffic and higher ratios for biomass burning release from measurements made at a small village over the steep Alpine valley of Roveredo, Switzerland. Saarikoski et al. (2008) observed an OC/EC ratio of 6.6 for biomass burning and 0.71 for vehicular emissions, whereas Sandradewi et al. (2008) found values of 7.3 and 1.1 for these two sources, respectively. Hopkins et al. (2007) studied the particles emitted during combustion of several plant fuels at different temperatures and suggested that flaming conditions produce more EC and less OC while smoldering fires result in higher OC content. Regional air quality over the northwestern part of India during winter season is considerably influenced by the annual practice of crop harvesting. However, wood/coal burning for domestic use continues throughout the year (Ram et al., 2010). Based on an extensive campaign at the top of 
(a) Winter

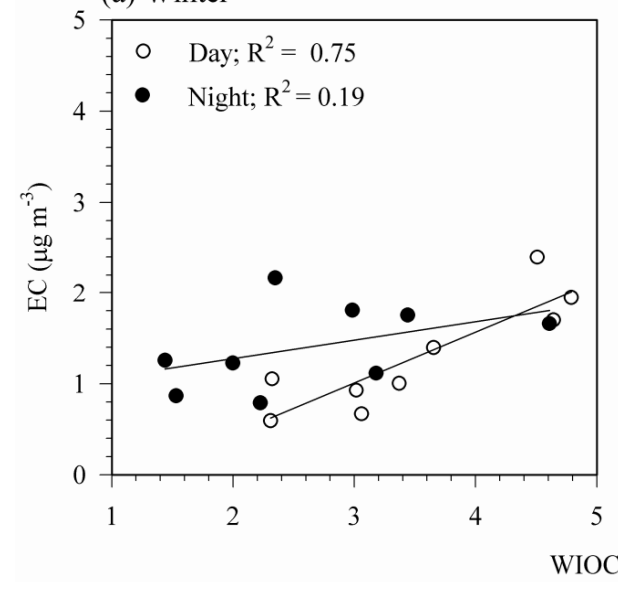

(b) Summer

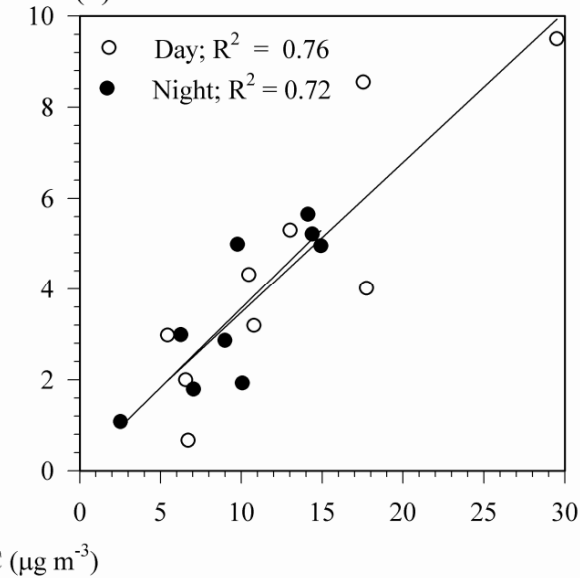

Fig. 4. Scatter plots between water insoluble organic carbon (WIOC) and elemental carbon (EC) during (a) winter and (b) summer seasons showing a linear relation.

a mountain site (1960 m a.s.l.) over a remote part of the Tibetan Plateau (Yunnan Province), Engling et al. (2011) reported higher OC/EC ratios (4.3 \pm 2.1$)$ during spring (April and May). This experiment also revealed a substantial regional build-up of carbonaceous particles accompanied by fire activities and transport of pollutants from nearby regions of Southeast Asia and the northern part of the Indian Peninsula.

The major part of aerosol carbon is derived from smoldering in the form of water-soluble organics and it can also act as cloud condensation nuclei (CCN) (Andreae et al., 1996). Carbonaceous aerosols derived from fossil fuel combustion may be relatively less water-soluble (WSOC; 7 to 19\%) due to less oxygenated organics as reported by Ruellan and Cachier (2001). The contributions of WSOC to the total carbon in our samples are $59 \%$ in winter and $32 \%$ in summer, with negligible differences between day and night ( $5 \%)$. The determination of both water-soluble and insoluble organic carbon can provide additional information regarding the carbon sources. The main component of OC in TSPM samples was found to be water-insoluble organic carbon (WIOC), which contributes considerably to OC and is defined as OC-WSOC. The correlation scatter plots for WIOC with EC for winter and summer seasons are shown in Fig. 4a and $\mathrm{b}$, respectively. A good correlation between WIOC and EC was apparent (except for winter night samples), indicating the influence of fossil fuel combustion over the study region. Further, lower OC/TSPM weight ratios were observed $(0.09 \pm 0.02$ in winter and $0.21 \pm 0.15$ in summer), indicating a significant contribution from other inorganic constituents to bulk aerosols. At high altitude locations over northwestern part of India, Mount Abu (Rastogi and Sarin, 2009) and a remote site over Tibetan Plateau, Yunnan Province (Engling et al., 2011), similar OC/TSPM weight ratios (0.09 and 0.16 , respectively) were reported. Organic matter (OM), was calculated by multiplying OC by a factor of 1.6 (Turpin and Lim, 2001). OM accounted for less than $15 \%$ of TSPM in winter and more than $35 \%$ of the particle mass in summer. Compared to OM, EC is minor component, contributing for less than $6 \%$ of the particle mass (EC annual average $2.85 \mu \mathrm{g} \mathrm{m}^{-3}$ ).

Primary OC (POC) is produced both from natural (primary biogenic particles) as well as anthropogenic sources. Anthropogenic POC can be directly emitted in particulate form by emission sources like vehicular exhaust, fuel combustion and cooking. In contrast, secondary OC (SOC) is formed through gas/particle partitioning of semi-volatile reaction products involving reactive organic gases (Blando and Turpin, 2000). Due to a lack of direct analytical chemical method, separating primary and secondary organic aerosol and enormous complexity of organic aerosols have limited researchers to estimating POC and SOC using EC tracer methods (Lim and Turpin, 2002). EC is one of the good tracers of primary combustion-generated carbonaceous aerosols (Yu et al., 2009). The limitation of the EC tracer method is to assume a representative ratio of primary $\mathrm{OC} / \mathrm{EC}$ for a given area because EC and POC typically have the same source (Miyazaki et al., 2006). By this method, POC and SOC were estimated using the following equations,

$[\mathrm{POC}]=[\mathrm{OC} / \mathrm{EC}]_{\min } \times[\mathrm{EC}]+c$

$[\mathrm{SOC}]=[\mathrm{OC}]_{\text {meas }}-[\mathrm{POC}]$

in which $[\mathrm{OC} / \mathrm{EC}]_{\min }$ is the minimum ratio of $\mathrm{OC} / \mathrm{EC}$ for all the samples in every season, $c$ is the parameter to account for non-combustion sources contributing to POC, and $[\mathrm{OC}]_{\text {meas }}$ is the measured OC concentration. In Eq. (1) we used the $[\mathrm{OC} / \mathrm{EC}]_{\min }$ values of $2.15 \mathrm{\mu g} \mathrm{m}^{-3}$ and $1.91 \mu \mathrm{g} \mathrm{m}^{-3}$ for winter and summer seasons, respectively. If we postulate that the POC contribution from non-combustion sources (e.g., primary biogenic sources) is negligible, $[\mathrm{OC} / \mathrm{EC}]_{\min }$ 


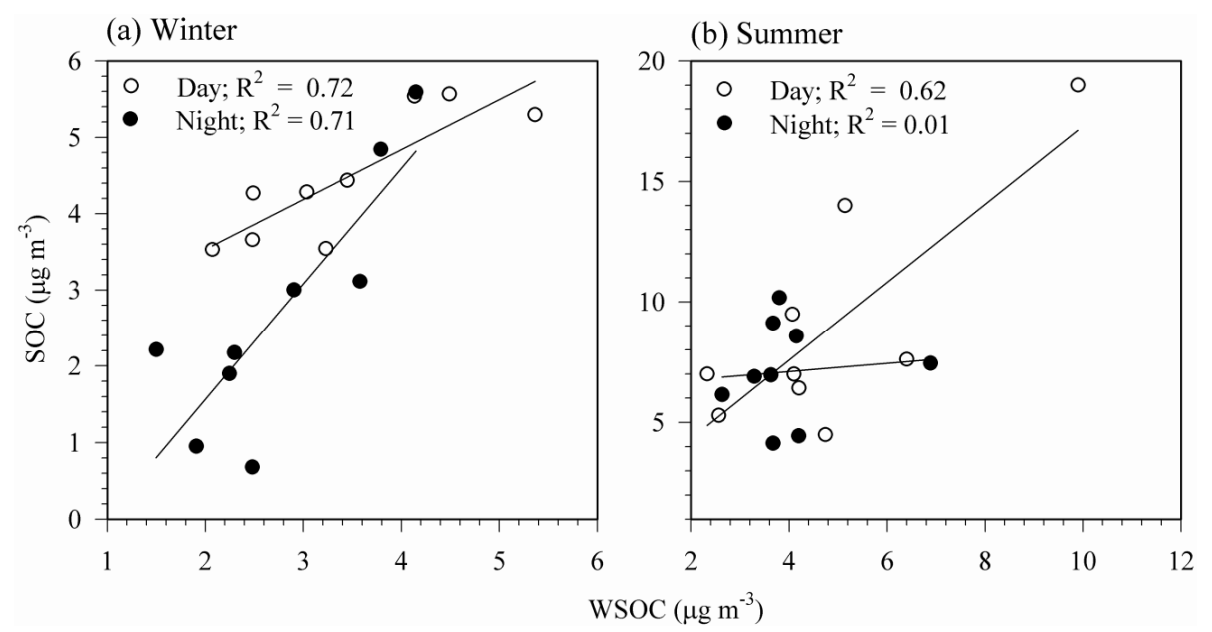

Fig. 5. Scatter plots between water-soluble organic carbon (WSOC) and secondary organic carbon (SOC) during (a) winter and (b) summer seasons showing a linear relation.

value used here seems to be reasonable because the OC/EC ratio depends upon the type of biomass as well as burn rate (Stone et al., 2010). In our samples POC concentrations were $2.8 \pm 1.1 \mu \mathrm{g} \mathrm{m}^{-3}$ in winter and $9.5 \pm 5.9 \mu \mathrm{g} \mathrm{m}^{-3}$ in summer. Similarly, SOC concentrations were $3.3 \pm 1.3 \mu \mathrm{g} \mathrm{m}^{-3}$ in winter and $7.7 \pm 3.2 \mu \mathrm{g} \mathrm{m}^{-3}$ in summer. The observed higher SOC/POC ratios (1.2) during winter than summer (0.8) suggest an enhanced photochemical production of organics under favorable meteorological conditions with a possible development of inversion layer and also increased photochemical production of SOC during the transport of organic pollutants from the source regions of Indo-Gangetic Basin.

In order to evaluate the possible uncertainties associated with the assumption of $[\mathrm{OC} / \mathrm{EC}]_{\min }$ values representative for primary combustion-generated carbonaceous aerosols, the following exercise has been performed. For the estimate of SOC, instead of the minimum value of the OC/EC ratio, we considered the lowest $10 \%$ of OC/EC values from each season. Lim et al. (2002) have shown that lowest $10 \%$ of OC/EC ratios are likely contributed by primary carbonaceous aerosols. The SOC values calculated using the lowest $10 \%$ of OC/EC ratios are always lower than those estimated using the minimum $\mathrm{OC} / \mathrm{EC}$ ratio by definition. The uncertainty for the average SOC was $28 \%$ and $39 \%$ for winter and summer, respectively. The observed uncertainties in the present study are comparable to the reported values in the literature for Tokyo (28\%) (Miyazaki et al., 2006) and Chennai (22\%) (Pavuluri et al., 2010).

Scatter plots of WSOC and SOC are given in Fig. 5. WSOC and SOC are highly correlated $\left(R^{2} \geq 0.62\right)$, except for summer nighttime samples. The slopes with $95 \%$ confidence intervals of the correlation were noticeably different. In contrast, WSOC is weakly correlated with POC $\left(R^{2} \leq\right.$ 0.40 ) for both seasons. The high concentrations of SOC and WSOC/OC ratios (av. $0.41 \pm 0.14 ; n=38$ ) as well as good correlations between SOC and WSOC suggest that the secondary production of organic aerosols during long-range atmospheric transport is significant over the study region. It is of interest to note that the average WSOC/SOC weight ratios were less than unity for most of the samples (av. 0.92 \pm 0.82 ; $n=38$ ). This finding may suggest that not all the SOC compounds were necessarily water-soluble; some SOC compounds are considered to have large carbon-hydrogen functional groups, leading to an enhanced insolubility (Saxena and Hildemann, 1996). Similar findings to our observations have been reported by Pavuluri et al. (2010) for the tropical coastal city of Chennai, India.

\subsection{Molecular characteristics of dicarboxylic acids and related compounds}

Various chemical species were identified in the aerosol samples from Nainital including saturated dicarboxylic acids (normal chain; $\mathrm{C}_{2}$ to $\mathrm{C}_{12}$ and branched chain; $\mathrm{iC}_{4}$ to $\mathrm{iC}_{6}$ ), unsaturated aliphatic diacids (maleic, fumaric, and methylmaleic), aromatic diacids (phthalic, isophthalic, and terephthalic), diacids with additional functional group, i.e., malic (hydroxysuccinic), ketomalonic, and 4-ketopimelic acids, together with $\omega$-ketoacids $\left(\mathrm{C}_{2}\right.$ to $\mathrm{C}_{9}$ except for $\left.\mathrm{C}_{6}\right), \alpha$-ketoacid (pyruvic), and $\alpha$-dicarbonyls (glyoxal and methylglyoxal). Concentrations of organic species are given in Table 1 along with EC, OC, TC and WSOC mass concentrations. Average molecular distributions of diacids, ketoacids, and $\alpha$ dicarbonyls in aerosol samples are shown in Fig. 6. It is quite clear that during winter season, nighttime average concentrations of $\mathrm{C}_{3}, \mathrm{C}_{4}, \mathrm{C}_{6}, \mathrm{iC}_{5}, \mathrm{M}, \mathrm{Ph}$ and $\omega \mathrm{C}_{9}$ were significantly higher than the averaged daytime concentrations (Fig. 6). This nighttime high was not observed during summer season when average concentrations were slightly lower than the daytime concentrations. 


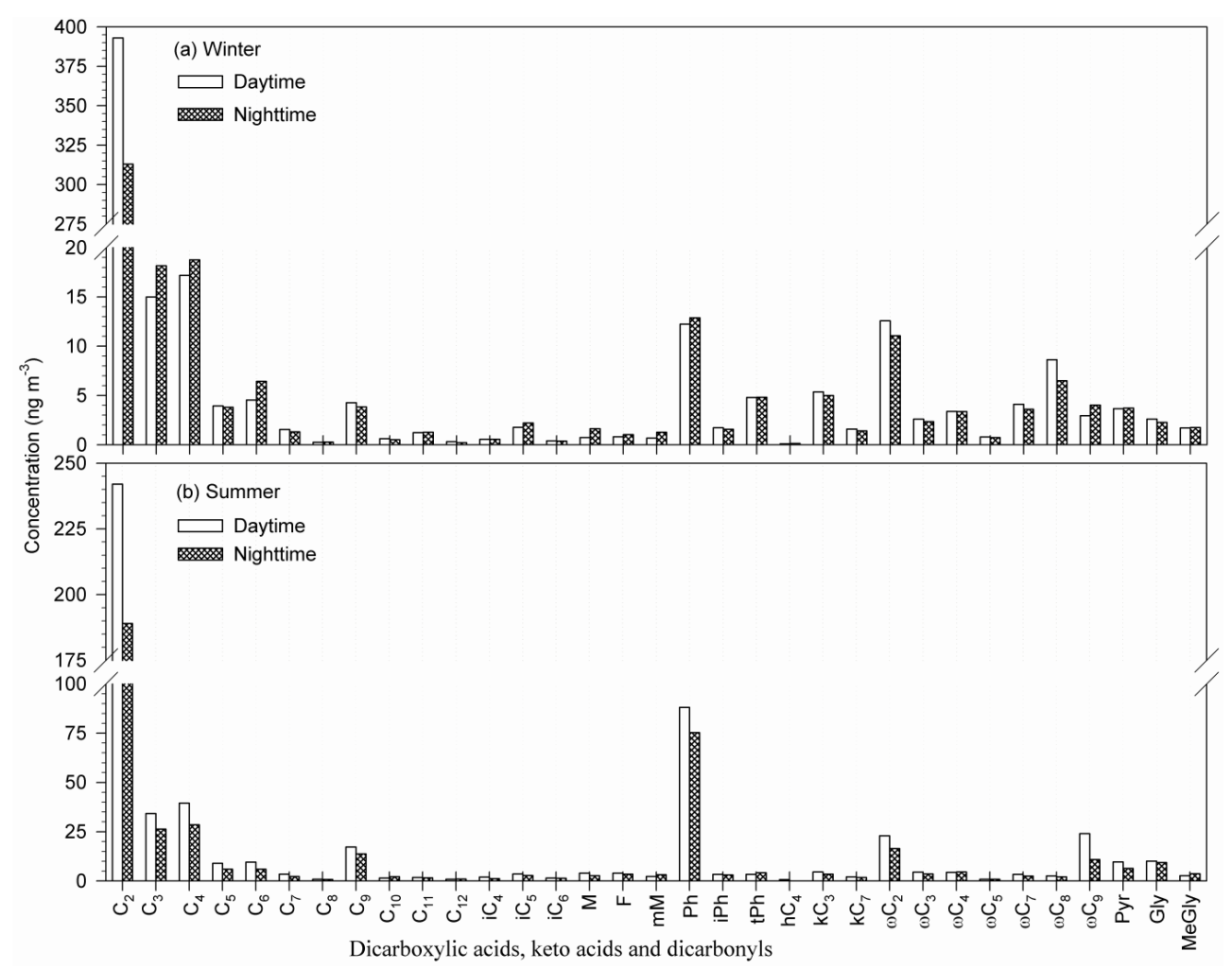

Fig. 6. Average molecular distributions of dicarboxylic acids (diacids), ketocarboxylic acids (ketoacids), and $\alpha$-dicarbonyls in aerosol samples collected at Nainital, India. See Table 1 for abbreviations.

The relative abundances (\%) of the individual diacids in total straight-chain diacids are shown as pie diagrams in Fig. 7. The abundances of compounds did not show any inversed relation with an increase in carbon chain length, which is generally observed for normal dicarboxylic acids (Ho et al., 2010; Pavuluri et al., 2010 and references therein). During winter, oxalic acid $\left(\mathrm{C}_{2}\right)$ was the most abundant diacid species ( $83 \%$ and $78 \%$ for day and night, respectively) followed by succinic $\left(\mathrm{C}_{4} ; 3.6 \%\right.$ and $\left.4.7 \%\right)$ and malonic $\left(\mathrm{C}_{3} ; 3.2 \%\right.$ and $4.5 \%$ ) acids, being consistent with the findings of previous studies (e.g., He and Kawamura, 2010). Contributions of phthalic $(\mathrm{Ph} ; 2.6 \%$ and $3.2 \%)$, adipic $\left(\mathrm{C}_{6} ; 1.0 \%\right.$ and $\left.1.6 \%\right)$ and azelaic $\left(\mathrm{C}_{9} ; 0.9 \%\right.$ and $\left.1.0 \%\right)$ acids were also significant. Other dicarboxylic acids contributed less than $1 \%$. Among ketoacids, glyoxylic acid $\left(\omega \mathrm{C}_{2}\right)$ was the most abundant, comprising $30 \%$ by mass. Glyoxal was generally more abundant than methylglyoxal (Table 1). This relative abundance is in contrast to urban aerosols from Tokyo, where methylglyoxal is always more abundant than glyoxal (Kawamura and Yasui, 2005). Similarly, for the summer period also, oxalic acid $\left(C_{2}\right)$ was the dominant diacid (50\% and $49 \%$ for day and night, respectively) along with succinic $\left(\mathrm{C}_{4} ; 8.2 \%\right.$ and $\left.7.5 \%\right)$, malonic $\left(\mathrm{C}_{3} ; 7.1 \%\right.$ and $\left.6.9 \%\right)$, phthalic $(\mathrm{Ph} ; 18.4 \%$ and $18.8 \%)$, azelaic $\left(\mathrm{C}_{9} ; 3.60 \%\right.$ and $\left.3.62 \%\right)$ and adipic $\left(\mathrm{C}_{6} ; 1.9 \%\right.$ and $1.6 \%)$ acids.
Concentrations of total diacids over Nainital varied from 295 to $620 \mathrm{ng} \mathrm{m}^{-3}$ with an annual mean of $433 \pm 108 \mathrm{ng} \mathrm{m}^{-3}$. These values are comparable to those from Chennai (a megacity in India; $227-1030 \mathrm{ng} \mathrm{m}^{-3}$, av. $612 \mathrm{ng} \mathrm{m}^{-3}$ ) and those from Tokyo (90-1360 $\mathrm{ng} \mathrm{m}^{-3}$, av. $480 \mathrm{ng} \mathrm{m}^{-3}$ ) (Kawamura and Ikushima 1993), Hong Kong (224-1381 $\mathrm{ng} \mathrm{m}^{-3}$, av. $692 \mathrm{ng} \mathrm{m}^{-3}$ ) (Ho et al., 2006), and a Gosan site, Jeju Island, Korea (130-2070 $\mathrm{ng} \mathrm{m}^{-3}$, average $660 \mathrm{ng} \mathrm{m}^{-3}$ ) (Kawamura et al., 2004) but slightly higher than those reported in Sapporo (106-787 $\mathrm{ng} \mathrm{m}^{-3}$, av. $406 \mathrm{ng} \mathrm{m}^{-3}$ ) (Aggarwal and Kawamura, 2008). The observed total diacid concentrations were similar to those for winter and summer seasons, but daytime concentrations were $80 \%$ higher than nighttime concentrations for the both seasons over Nainital. The contribution of total diacids to TSPM was slightly higher (by $20 \%$ ) in winter than summer. Day and night differences were least for both the seasons $(<6 \%)$.

The diacid-carbon/OC ratios are good tracers for pollution sources (Aggarwal et al., 2010). In Nainital aerosols the diacid-C/OC ratios during winter and summer were $2.2 \%$ and $1.2 \%$, respectively. The annual average diacid-C/OC ratios $(1.7 \pm 0.7)$ are comparable to and/or lower than those obtained at Asian megacities like New Delhi, India (1.0\%) (Miyazaki et al., 2009), and in Sapporo, Japan (4.8\%) (Aggarwal and Kawamura, 2008). Interestingly, they are several times higher than that from auto exhaust (winter: $0.51 \%$; 

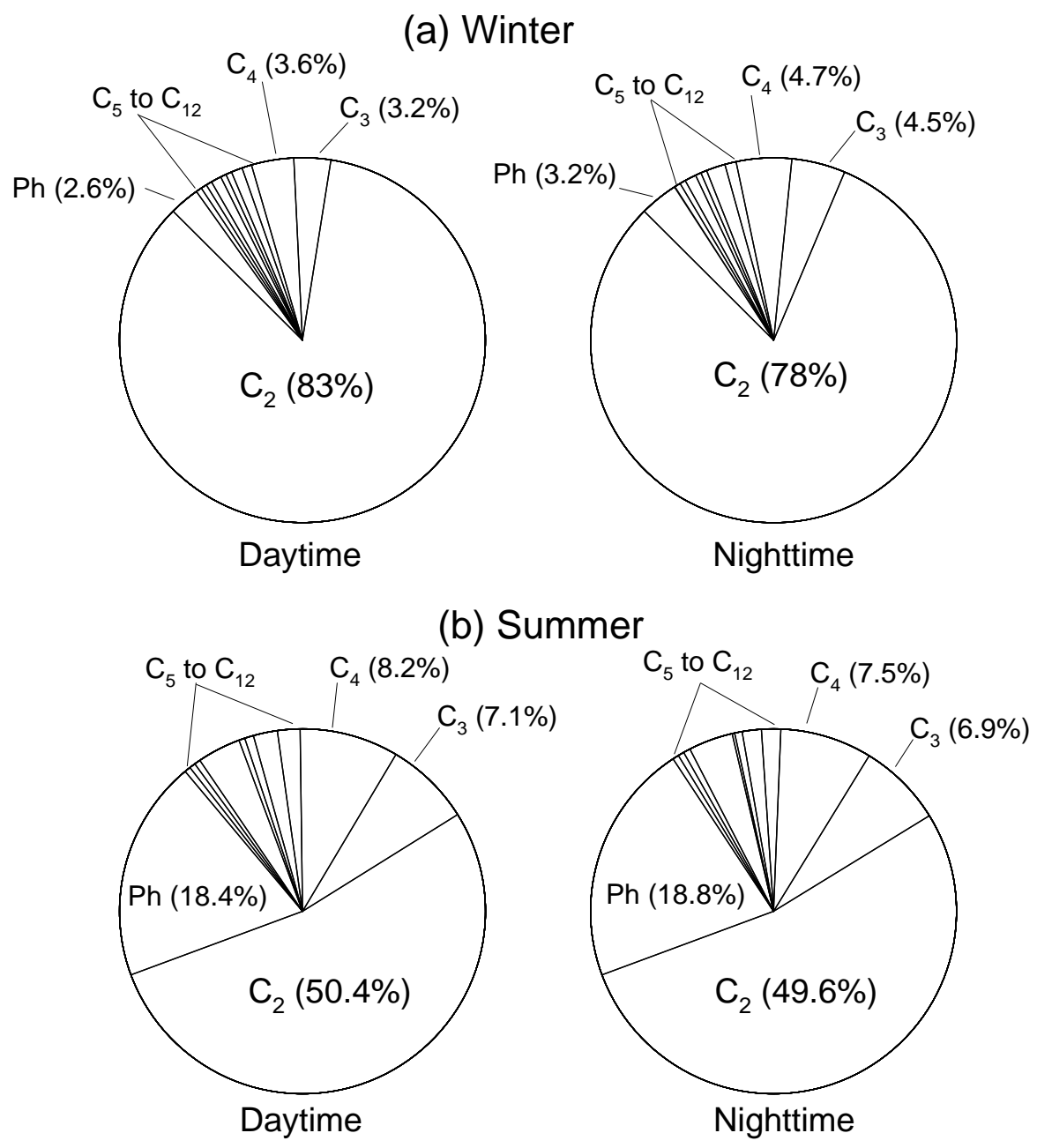

Fig. 7. Pie diagrams of relative abundances (\%) of individual diacid in total straight-chain diacids in aerosols collected during (a) winter and (b) summer seasons in Nainital, India.

summer: $0.41 \%$ ) (Wang et al., 2006a), but comparable to that from biomass burning (daytime: $1.7 \%$; nighttime: $1.4 \%$ ) (Kundu et al., 2010), suggesting that the Nainital aerosols are largely influenced by biomass burning, especially during the winter period.

During photochemical production of diacids, contributions of diacid-carbon (diacid-C) to aerosol total carbon (TC) increase in the urban atmosphere (Kawamura and Yasui, 2005; Jung et al., 2010). In the Nainital aerosols the diacid-C/TC ratios during wintertime were $1.7 \%$ and $1.8 \%$ for day and night, respectively, whereas during summertime the contributions were almost halved $(0.84 \%$ for day and $0.75 \%$ for night). The diurnal differences were minimum and opposite between the two seasons. The observed lower diacid$\mathrm{C} / \mathrm{TC}$ ratios during summer indicate not only less photochemical aging but also the enhanced contribution from hydrophobic carbonaceous aerosols from combustion sources (Aggarwal and Kawamura, 2008; Jung et al., 2010). However, many other polar organic species (e.g., carbohydrate- like substances) also can contribute to TC and cannot be ruled out (Stone et al., 2009). The annual average diacidC/TC ratio at Nainital $(1.3 \%)$ is slightly higher than or comparable to those obtained at Asian megacities in Tokyo $(0.95 \%)$ (Kawamura and Ikushima, 1993), capital of Mongolia - Ulaanbaatar (0.6\%) (Jung et al., 2010) and Sapporo, Japan (1.8\%) (Aggarwal and Kawamura, 2008). In megacity Chennai, southwest coast of India, a similar annual average value $(1.58 \%$ ) was obtained by Pavuluri et al. (2010), but considerably higher ratios were found during the summer period. On the other hand, studies conducted over remote marine regions like the tropical to western North Pacific (8.5\%) (Kawamura and Sakaguchi, 1999) and in the western Pacific (3.2\%) (Sempéré and Kawamura, 2003) recorded several times higher diacid-C/TC ratios than Nainital due to significant photochemical processing (Kawamura and Sakaguchi, 1999).

During winter the total ketocarboxylic acid concentrations were $39 \pm 12 \mathrm{ng} \mathrm{m}^{-3}$ and $35 \pm 14 \mathrm{ng} \mathrm{m}^{-3}$ in day and 
night, respectively, whereas during summer the concentrations were almost double $\left(72 \pm 46 \mathrm{ng} \mathrm{m}^{-3}\right.$ in day and $47 \pm 18 \mathrm{ng} \mathrm{m}^{-3}$ in night). Interestingly, for the cold winter season, the day and nighttime differences were small ( $10 \%)$, but for hot summer period the daytime concentrations of several ketocarboxylic acid species were much higher ( $50 \%)$ than nighttime. The relatively small diurnal amplitude in winter may be caused by slower production and destruction rates of the compounds (less availability of oxidants). Most of the $\omega$-oxoacids are semi-volatile and may likely be subjected to evaporation from the particles to gas phase when the ambient temperature increases. However, this process does not seem to affect net production seriously because their concentrations in aerosols rather increase in daytime. The mass ratios of total ketoacid to TSPM were significantly higher during summer than winter. Concentrations of $\alpha$-dicarbonyls (glyoxal and methylglyoxal) also showed maxima during the summer period (Table 1). Similarly, the mass ratios of total $\alpha$-dicarbonyls to TSPM were remarkably higher for summer (almost 3 times). The summertime high concentrations seem to be associated with increased solar radiation (Ho et al., 2006). The daytime concentrations were slightly higher (by $\sim 10 \%$ ) than nighttime concentrations for both the seasons.

Oxalic acid $\left(\mathrm{C}_{2}\right)$ is the most abundant diacid species reported in the literature (e.g., Kawamura and Kaplan, 1987; Kawamura and Ikushima, 1993; Gao et al., 2003). The predominance of oxalic acid in Nainital aerosols is consistent with previous studies from urban, coastal marine and remote marine aerosols (Kawamura and Sakaguchi, 1999; Wang et al., 2006b), because this smallest diacid is a final product of the photochemical chain oxidations of aromatic hydrocarbons, isoprene, ethylene, and acetylene (Ervens et al., 2004) and may also be directly contributed from fossil fuel combustion (Kawamura and Kaplan, 1987) and biomass burning (Narukawa et al., 1999). During the winter period, oxalic acid concentrations were $393 \pm 78 \mathrm{ng} \mathrm{m}^{-3}$ and $313 \pm 88 \mathrm{ng} \mathrm{m}^{-3}$ for day and night, respectively. In contrast, during summertime $\mathrm{C}_{2}$ concentrations became $\sim 60 \%$ lower than winter in both day and night samples. The summertime low concentrations seem to be closely associated with two different air mass pathways reaching the sampling site for individual seasons. From the air mass trajectories (Fig. 1) it is apparent that during early winter the winds circulate mostly over the densely populated Indo Gangetic Plain while during summer air masses remain westerly/southwesterly. Aerosol characterization studies over the Indo Gangetic Plain (Moorthy et al., 2007) as well as southwestern Himalayan region (Hegde et al., 2007; Gautam et al., 2010) revealed the existence of elevated dust layers during the pre-monsoon season (April, May and June).
The higher concentration of oxalic acid during winter may be associated with the contribution of isoprene to $\mathrm{C}_{2}$ formation. Lim et al. (2005) and Myriokefalitakis et al. (2011) proposed $\mathrm{C}_{2}$ production through isoprene oxidation in which glyoxal, methylglyoxal, pyruvic acid and glyoxylic acid are the intermediate compounds. It is important to note that oxalic acid is the ultimate diacid in the reaction scheme of oxidation of isoprene (without involving longer chain diacids). Isoprene is ubiquitous in the troposphere at a mixing ratio of about $0.1-7.0 \mathrm{ppb}$ depending on season and location (von Kuhlmann et al., 2004). Measurements conducted by Padhy and Varshney (2005) over New Delhi and surrounding areas revealed significant annual average isoprene emission of $6.2 \pm 3.2 \mu \mathrm{g} \mathrm{g}^{-1}$ leaf dry weight $\mathrm{h}^{-1}$ (average of six commonly grown tree species) with higher isoprene emission during September and October. Thus, formation of oxalic acid from isoprene may be enhanced during winter months in the Himalayan region.

The photochemical degradation of oxalate-iron complex and the relative depletion of oxalic acid during summer months seem to be associated with the type of air mass reaching Nainital. It has been shown that dust particles that contain alkaline and trace metals may interact with organic acids by forming organo-metal complexes (Deguillaume et al., 2005). For example, in an aerosol liquid phase, oxalic acid is an important ligand-ion for dissolving hydrated iron oxide. In the atmospheric liquid phases, the significance of this mixed complex depends on the concentrations of the potential ligands and on the value of the associated stability constant. So far there have been no measurements to determine the chemical forms of iron in complex media such as the atmospheric liquid phase. However, Willey et al. (2000) showed that iron (III) occurred predominantly as a complex with oxalate in continental summer rain, whereas in continental winter rain iron-oxalate and ferrous hydroxide were almost equal in concentration. The photolysis processes of the iron-oxalate complexes are therefore considered to be an efficient pathway for the destruction of oxalic acid during the summer period (Pavuluri and Kawamura, 2012). Ho et al. (2007) have observed significantly lower oxalic acid concentrations for the summer season as compared to winter in a study conducted over 14 Chinese cities. Over the northern part of Indian subcontinent high dust loading rich in mineral aerosols (especially iron content) has been reported during the summer season (Chinnam et al., 2006 and references therein). Kawamura et al. (2010) also reported a similar depletion of oxalic acid relative to other diacids in Arctic aerosols during the polar sunrise (spring season). They suggested that oxalic acid can be selectively decomposed under strong solar radiation in the presence of Fe. This hypothesis needs to be verified by taking into account the concentrations of $\mathrm{Fe}$ in aerosols in future study. 
(a) Winter

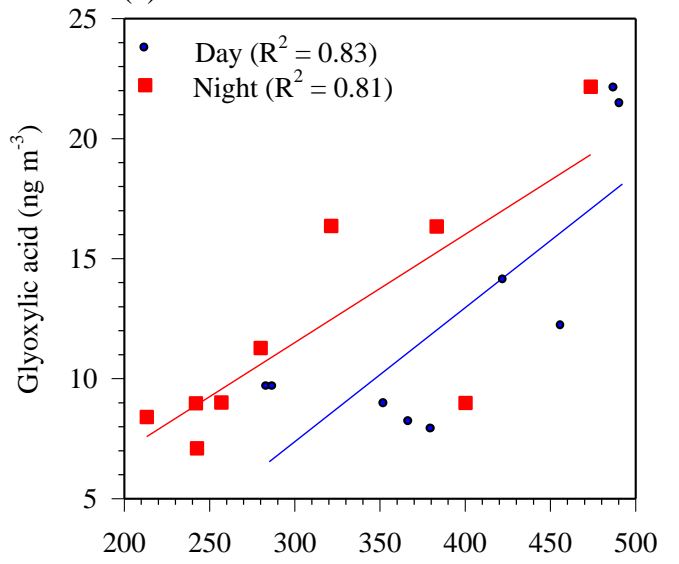

(b) Summer

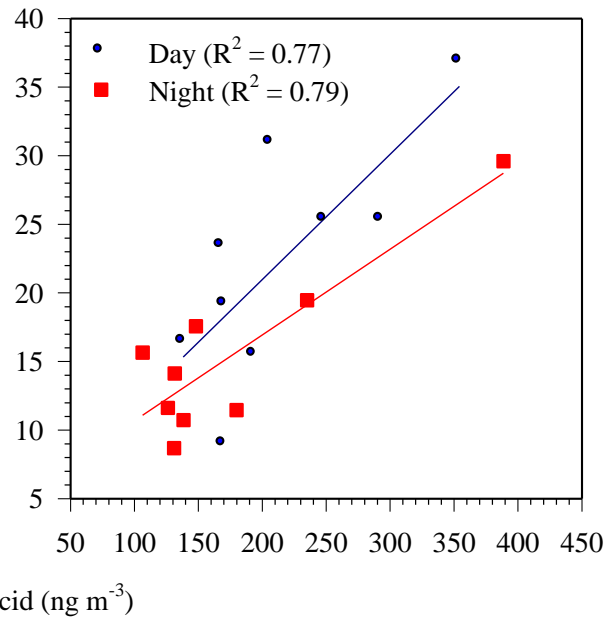

Fig. 8. Scatter plots between oxalic $\left(\mathrm{C}_{2}\right)$ and glyoxylic $\left(\omega \mathrm{C}_{2}\right)$ acids during (a) winter and (b) summer seasons showing a linear relation.

\subsection{Formation and transformation mechanisms of dicarboxylic acids}

Two types of atmospheric reactions form oxalic, malonic and succinic acids (Kawamura et al., 1996a). One is the oxidation of unsaturated fatty acids, which is reported over the remote marine atmosphere such as the Pacific Ocean (Kawamura and Sakaguchi, 1999). Unsaturated fatty acids can originate from phytoplankton in the marine region and domestic cooking as well as higher plants in the continental region. In the first route, succinic acid is produced by oxidation of unsaturated acid (e.g., oleic acid; Kawamura and Sakaguchi, 1999) and then malonic and succinic acids are produced on further oxidation of succinic acid (Kawamura and Ikushima, 1993). Interestingly, we found good correlation of succinic and malonic acids with oxalic acid $(R=0.91$ and 0.92 , respectively) only for summer samples in this study, indicating a potential source from the oxidation of unsaturated fatty acids. The second possible pathway is the production from aromatic hydrocarbons such as benzene and toluene (Kawamura and Ikushima, 1993). In this route, glyoxal and glyoxylic acid are intermediates in the formation of oxalic acid but succinic and malonic acids are not produced. Good correlations were obtained for glyoxal and oxalic acid $(R=0.61)$ and glyoxylic acid and oxalic acid $(R=0.76)$ particularly during winter period, which supports this formation pathway. More detailed discussion on this formation pathway is given below.

Biogenic and anthropogenic VOCs can react with oxidants to produce glyoxal (Gly) and methylglyoxal (MeGly) in the gas phase in both daytime and nighttime. Gly and MeGly can be further hydrated in an aqueous phase to form $(\mathrm{OH})_{2} \mathrm{CHCH}(\mathrm{OH})_{2}$ and, $\mathrm{CH}_{3} \mathrm{COCH}(\mathrm{OH})_{2}$, respectively. Hydrated MeGly can be further oxidized to pyruvic acid, acetic acid and hydrated glyoxylic acid, which will eventually be converted to oxalic acid. In contrast, hydrated Gly can be oxidized to glyoxylic acid $\left(\omega \mathrm{C}_{2}\right)$, and ultimately to oxalic acid (Lim et al., 2005). In our samples, very good correlations $(R \geq 0.8)$ were observed between $\mathrm{C}_{2}$ with $\omega \mathrm{C}_{2}$, pyruvic acid, glyoxal and methylglyoxal especially during the winter period, supporting the above formation mechanism. Figure 8 gives the correlation between $\mathrm{C}_{2}$ with $\omega \mathrm{C}_{2}$ for both seasons. We found that comparatively more $\mathrm{C}_{2}$ is produced in nighttime summer aerosols, as the concentrations of $\omega \mathrm{C}_{2}$ become lower in nighttime than daytime. However, during the winter period an opposite trend was observed (Fig. 8a).

During summertime, the successive oxidation reactions of $\mathrm{C}_{5}$ into shorter chain diacids are more effective (Ervens et al., 2004). In our samples, high correlation coefficients $(R \geq 0.7)$ were observed among $\mathrm{C}_{2}-\mathrm{C}_{5}$ diacids only during the summer period, suggesting that they are either primarily emitted (or quickly secondarily produced) together with a dominant fraction as oxalic acid (i.e., direct production, vehicular emission, wood combustion, meat cooking operations) or strongly connected to each other in the chain reactions transforming glutaric acid into oxalic acid.

The ratio of $\mathrm{C}_{2} /$ total dicarboxylic acids can be used to assess the aging process of organic aerosols, although $\mathrm{C}_{2}$ could be subject to photolysis under certain situation as discussed in the previous section. Typically, higher ratios are observed with the progress of aerosol aging (Kawamura and Sakaguchi, 1999). In Nainital aerosols the concentration of $\mathrm{C}_{2}$ are significantly higher in daytime than in nighttime (for the same date). The average daytime to nighttime concentration ratio of $\mathrm{C}_{2}$ is $\sim 1.3$ for both seasons. Considerable temporal variations are also observed. The $\mathrm{C}_{2} /$ total diacid ratios show higher values in winter $\left({ }^{\circ} 0.8 \pm 0.04\right)$ than summer $(\sim 0.5 \pm 0.01)$, suggesting that the winter aerosols may be more aged (Fig. 9a). As the anthropogenic aerosols that are emitted from the industrial regions of Indo Gangetic Plain areas 


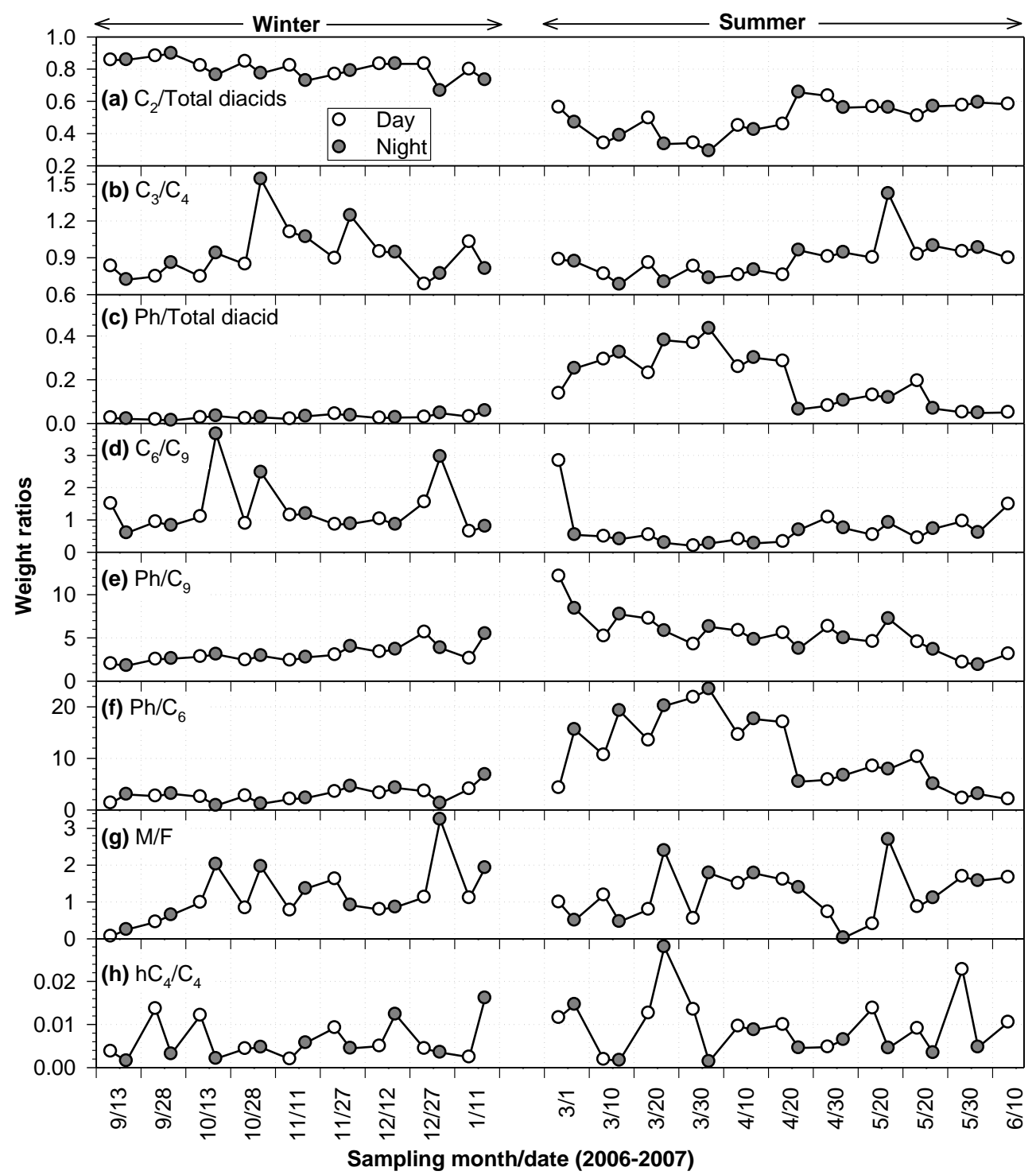

Fig. 9. Temporal variations in concentration (weight) ratios of (a) $\mathrm{C}_{2} /$ total diacids, (b) $\mathrm{C}_{3} / \mathrm{C}_{4},(\mathbf{c}) \mathrm{Ph} /$ total diacids, (d) $\mathrm{C}_{6} / \mathrm{C}_{9}$, (e) $\mathrm{Ph} / \mathrm{C}_{9}$, (f) $\mathrm{Ph} / \mathrm{C}_{6},(\mathbf{g}) \mathrm{M} / \mathrm{F}$ and $(\mathbf{h}) \mathrm{hC}_{4} / \mathrm{C}_{4}$ in aerosol samples collected at Nainital, India.

can travel to the north and reach the sampling site by the northerly wind (comparatively lower temperature and weaker wind speed) during the winter period, aging of these aerosols might occur during the transport and thereby significantly contribute to the higher $\mathrm{C}_{2} /$ total diacid ratios. In contrast, this trend is reversed during summer. Because the temperature over the region increase and high wind favors quick transport of pollutants, fresher aerosols are transported over the sampling site. For the oxalic acid production, aqueous phase chemistry in aerosol/cloud/fog droplets plays a major role (Warneck, 2003). Because solar radiation was reduced and relative humidity was considerably high on several occasions during the winter period ( $>90 \%$ especially during western disturbances), it is possible that $\mathrm{C}_{2}$ can be produced in aqueous phase during the cold phase of aging.
Malonic to succinic acid ratios $\left(\mathrm{C}_{3} / \mathrm{C}_{4}\right)$ have been extensively used to evaluate the secondary production of dicarboxylic acids in the atmosphere (Kawamura and Ikushima 1993; Yao et al., 2004). Malonic acid $\left(\mathrm{C}_{3}\right)$ is derived from the incomplete combustion of fossil fuels or from the secondary atmospheric production. Kawamura and Ikushima (1993) reported that $\mathrm{C}_{3} / \mathrm{C}_{4}$ ratios for vehicular exhaust are lower $(0.25-0.44$, average 0.35$)$ than those of atmospheric aerosols (0.56-2.9, average 1.6) because malonic acid is thermally less stable than succinic acid; the degradation of malonic acid in the combustion process is probably more significant than its production. The temporal variations of $\mathrm{C}_{3} / \mathrm{C}_{4}$ mass concentration ratios over Nainital are shown in Fig. $9 \mathrm{~b}$. During winter period $C_{3} / C_{4}$ ratios were 0.88 for day and 0.95 for night, being similar to summer samples (0.85 and 0.90$)$. 
Table 2. Weight ratios of selected diacids in Himalayan aerosols with the literature data.

\begin{tabular}{llllll}
\hline Site/Type & Season & $\mathrm{C}_{3} / \mathrm{C}_{4}$ & $\mathrm{C}_{6} / \mathrm{C}_{9}$ & $\mathrm{Ph} / \mathrm{C}_{6}$ & $\mathrm{Ph} / \mathrm{C}_{9}$ \\
\hline Tokyo, Japan/urban $^{\mathrm{a}}$ & one year & 1.49 & 0.70 & 0.94 & 0.65 \\
Jeju Island, Korea/remote $^{\mathrm{b}}$ & one year & 1.29 & 1.79 & 1.17 & 2.09 \\
Nanjing, China/urbanc $^{\mathrm{c}}$ & summer & - & 0.51 & 3.88 & 1.98 \\
Nanjing, China/urban $^{\mathrm{c}}$ & winter & - & - & - & 1.00 \\
China/14 cities average $^{\mathrm{d}}$ & winter & 0.51 & 0.52 & 5.21 & 2.71 \\
China/14 cities average $^{\mathrm{d}}$ & summer & 0.77 & 0.75 & 4.48 & 3.37 \\
New Delhi, India/urban $^{e}$ & winter & 0.66 & 0.41 & 1.38 & 0.57 \\
Chennai, India/urban $^{f}$ & winter & 1.48 & 0.42 & 4.78 & 2.00 \\
Chennai, India/urban $^{f}$ & summer & 1.32 & 0.29 & 2.34 & 0.69 \\
This study $_{\text {This study }}$ & winter & 0.88 & 1.07 & 2.67 & 2.86 \\
\hline
\end{tabular}

${ }^{\mathrm{a}}$ Kawamura and Ikushima, (1993). ${ }^{\mathrm{b}}$ Kawamura et al. (2004).

${ }^{\mathrm{c}}$ Wang et al. (2002). ${ }^{\mathrm{d}}$ Ho et al. (2007). ${ }^{\mathrm{e}}$ Miyazaki et al. (2009).

${ }^{\mathrm{f}}$ Pavuluri et al. (2010).

It is quite clear from the figure that for most of the samples mass ratios are less than or equal to unity.

Relatively low $\mathrm{C}_{3} / \mathrm{C}_{4}$ diacid ratios have been found to be associated with the overwhelming contributions from vehicular exhaust to these acids in some studies, e.g., in downtown and west Los Angeles (Kawamura and Kaplan, 1987) and also in Nanjing, China (Wang et al., 2002). On the other hand, the mass ratio of $\mathrm{C}_{3} / \mathrm{C}_{4}$ in secondary atmospheric particles is much larger than unity (Kawamura and Ikushima, 1993; Kawamura and Sakaguchi, 1999; Yao et al., 2002). For example, Kawamura and Ikushima (1993) reported a maximum $\mathrm{C}_{3} / \mathrm{C}_{4}$ mass ratio of 3 during the summer in Tokyo. They found that larger ratios are concurrent with elevated concentrations of oxidants and attributed the source of dicarboxylic acids to secondary atmospheric reactions. Kawamura and Sakaguchi (1999) observed the $C_{3} / C_{4}$ ratio of 3 in the remote marine aerosols from the Pacific Ocean, where dicarboxylic acids are expected to originate from secondary reactions.

Phthalic acid is one of the most abundant species throughout the observation. It is produced in the atmosphere by photochemical oxidation of naphthalene and its alkylated forms, which are derived from incomplete combustion of fossil fuels. The temporal variations of $\mathrm{Ph} /$ total diacid concentration ratios are shown in Fig. 9c. Phthalic acid concentrations during wintertime were $12 \pm 2.8 \mathrm{ng} \mathrm{m}^{-3}$ for day and $13 \pm 5.6 \mathrm{ng} \mathrm{m}^{-3}$ for night. During summertime, its concentrations become 7 times higher than those in winter (Table 1; $88 \pm 55 \mathrm{ng} \mathrm{m}^{-3}$ for day and $75 \pm 54 \mathrm{ng} \mathrm{m}^{-3}$ for night). Interestingly, nighttime concentrations were marginally higher than daytime concentrations during the winter period, whereas during summer they showed an opposite trend, indicating different origin and transformation processes of $\mathrm{ph}$ thalic acid over the region.

Adipic $\left(\mathrm{C}_{6}\right)$ and phthalic $(\mathrm{Ph})$ acids are produced by the oxidation of anthropogenic cyclohexene and aromatic hydro- carbons, whereas azelaic $\left(\mathrm{C}_{9}\right)$ acid is from biogenic unsaturated fatty acids containing a double bond at C-9 position (Kawamura and Gagosian, 1987; Kawamura and Ikushima, 1993). Therefore, $\mathrm{C}_{6} / \mathrm{C}_{9}$ and $\mathrm{Ph} / \mathrm{C}_{9}$ ratios can be used as markers to evaluate the source strength of anthropogenic versus biogenic precursors to dicarboxylic acids. The temporal variations of $\mathrm{C}_{6} / \mathrm{C}_{9}$ and $\mathrm{Ph} / \mathrm{C}_{9}$ ratios are shown in Fig. $9 \mathrm{~d}$ and $\mathrm{e}$, respectively. The mean value of the $\mathrm{C}_{6} / \mathrm{C}_{9}$ ratio (1.07 and 0.56 for winter and summer samples, respectively) in our study is considerably higher than that for urban Chinese cities ( 0.52 for winter) and Tokyo $(0.70$ one year average ratio) aerosols, suggesting that adipic $\left(\mathrm{C}_{6}\right)$ acid is mostly derived from biomass burning especially during the winter season. The mean value of the $\mathrm{Ph} / \mathrm{C}_{9}$ ratio in our study is comparable to that of aerosols collected from Chinese megacities (Table 2) and significantly higher than urban Tokyo ( $>3$ times). This finding implies that the contribution of phthalic $(\mathrm{Ph})$ acid from other anthropogenic sources is more significant than that from biomass burning. In support of this, $\mathrm{Ph}$ to total diacids ratios are several times higher in all the summer samples than winter samples (Fig. 9c).

The study conducted by Kawamura and Kaplan (1987) reported that diesel fuel vehicular exhaust shows a higher $\mathrm{Ph} / \mathrm{C}_{6}$ ratio (6.58) than that from gasoline fuel vehicle (2.05). In Nainital aerosols also, phthalic/adipic $\left(\mathrm{Ph} / \mathrm{C}_{6}\right)$ ratios are greater than unity throughout the observation (Fig. 9f), suggesting that the sources from diesel fuel vehicles are more important for diacids than gasoline fuel vehicles. Interestingly, $\mathrm{Ph} / \mathrm{C}_{6}$ ratios were $\sim 10$ times higher on several occasions for summer samples, indicating the higher contribution from mobile sources than stationary sources. Similarly, higher $\mathrm{Ph} / \mathrm{C}_{6}$ ratios (1.17 to 5.21) were observed for urban areas like New Delhi and Chennai, India and several Chinese megacities (Table 2). These comparisons suggest that emissions from diesel fuel combustion contribute more to the aerosols over Nainital. 
Table 3. Results of principal component analyses on the selected dicarboxylic acids and related compounds in Himalayan aerosols.

\begin{tabular}{|c|c|c|c|c|c|c|}
\hline \multirow[t]{2}{*}{ Compounds } & \multicolumn{3}{|c|}{ Winter } & \multicolumn{3}{|c|}{ Summer } \\
\hline & Factor 1 & Factor 2 & Factor 3 & Factor 1 & Factor 2 & Factor 3 \\
\hline Oxalic $\left(\mathrm{C}_{2}\right)$ & 0.78 & & & 0.90 & & \\
\hline Malonic $\left(\mathrm{C}_{3}\right)$ & & 0.69 & & 0.92 & & \\
\hline Succinic $\left(C_{4}\right)$ & & 0.78 & & 0.96 & & \\
\hline Glutaric $\left(\mathrm{C}_{5}\right)$ & 0.58 & 0.72 & & 0.94 & & \\
\hline $\operatorname{Adipic}\left(\mathrm{C}_{6}\right)$ & & 0.82 & & 0.76 & & \\
\hline Azelaic $\left(\mathrm{C}_{9}\right)$ & & 0.67 & & & 0.83 & \\
\hline Maleic (M) & & 0.93 & & 0.63 & & \\
\hline Fumaric (F) & & 0.74 & & & & \\
\hline Phthalic (Ph) & & 0.67 & 0.60 & & 0.87 & \\
\hline Terephthalic (tPh) & & & 0.84 & & & 0.73 \\
\hline Glyoxylic $\left(\omega \mathrm{C}_{2}\right)$ & 0.80 & & 0.55 & 0.84 & & \\
\hline Pyruvic (Pyr) & 0.79 & & & 0.49 & 0.73 & \\
\hline Glyoxal (Gly) & 0.64 & & 0.68 & & 0.79 & \\
\hline Methylglyoxal (MeGly) & 0.74 & & & & 0.42 & \\
\hline Total variance (\%) & 50 & 18 & 7 & 36 & 23 & 10 \\
\hline
\end{tabular}

The trans configuration (fumaric $(\mathrm{F})$ ) is often more abundant than cis configuration (maleic acid (M)), as reported for the remote marine atmosphere (Kawamura and Sakaguchi, 1999). Photochemical oxidation of aromatic hydrocarbons such as benzene and toluene predominantly produce maleic acid, which can be further isomerized to fumaric acid in the atmosphere during long-range transport. The temporal variations of M/F ratios over Nainital are shown in Fig. 9g. During wintertime the $\mathrm{M} / \mathrm{F}$ ratios were $0.86 \pm 0.45$ and $1.46 \pm 0.92$ for day and night, respectively, whereas during summertime the ratios were higher $(1.00 \pm 0.44$ and $2.56 \pm 1.94$ for day and night, respectively). This difference is in contrast to the urban aerosols (0.8-3.9, average 1.5) (Kawamura and Ikushima, 1993) and marine aerosols (0.06-1.3, average 0.26; Kawamura and Sakaguchi, 1999). Kundu et al. (2010) observed that $\mathrm{M} / \mathrm{F}$ ratios in all day and night samples ranged from 0.3 to 5.6 (av. 2.8) at a pasture site in Rondonia, Brazil, during an intensive biomass-burning period. With the above discussion it is suggested that the isomerization of maleic (M) to fumaric (F) acid is suppressed under hazy conditions caused by biomass burning, in which sunlight is minimum during winter period whereas the opposite is observed in nighttime samples for both seasons.

The temporal variations of malic acid $\left(\mathrm{hC}_{4}\right) / \mathrm{C}_{4}$ ratios are shown in Fig. 9h. Kawamura and Ikushima (1993) conjectured, based on the field observation in the urban atmosphere, that $\mathrm{hC}_{4}$ can be photochemically generated from succinic acid $\left(\mathrm{C}_{4}\right)$ via hydroxylation. The $\mathrm{hC}_{4} / \mathrm{C}_{4}$ ratios have shown higher values in summer, supporting this hypothesis. The average $\mathrm{hC}_{4} / \mathrm{C}_{4}$ ratio (1.4) in summer was found to be 3 times higher than the winter season, being consistent with the observation in urban Tokyo (Kawamura and Ikushima, 1993). Similarly, almost doubled $\mathrm{hC}_{4} / \mathrm{C}_{4}$ ratios were ob- served during summer season for another megacity Chennai, India (Pavuluri et al., 2010).

\subsection{Relation between short chain dicarboxylic acids and WSOC}

Emissions from biomass burning as well as bio-fuel plume particles are reported to have large proportion of watersoluble organic species (Mayol-Bracero et al., 2002). Dicarboxylic acids in our samples show the predominance of $\mathrm{C}_{2}$ followed by $\mathrm{C}_{4}$ and $\mathrm{C}_{3}$. A similar molecular distribution was observed for aerosols from Indonesian forest fires (Narukawa et al., 1999) and European aerosols (Legrand et al., 2007). Figure 10a shows a strong positive correlation between $\sum\left(\mathrm{C}_{2}+\mathrm{C}_{3}+\mathrm{C}_{4}\right)$ (i.e., short chain diacids) and WSOC only for the winter period, suggesting a significant contribution from secondary biogenic sources. However, a poor correlation was observed for the summer period (Fig. 10b). This contrast indicates that WSOC and their precursors have different sources than short chain diacids during the summer period (Miyazaki et al., 2009). The observed high concentrations of several anthropogenic molecular markers (e.g., phthalic acid) only during summer season indicate the influence of anthropogenic sources on the increase in WSOC but not for short chain diacids.

\subsection{Principal component analysis for selected species}

Several types of mathematical models were used in the studies of aerosol chemical composition source apportionment. Factor analysis is a multivariate model for reducing matrices of data to their lowest dimensionality by the use of orthogonal factor space and transformations that yield predictions and/or recognizable factors (Malinowski, 1991). Factor 
(a) Winter

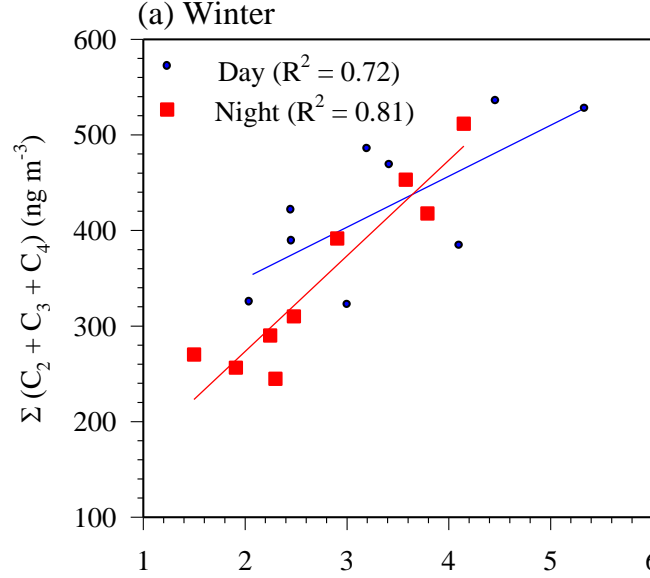

(b) Summer

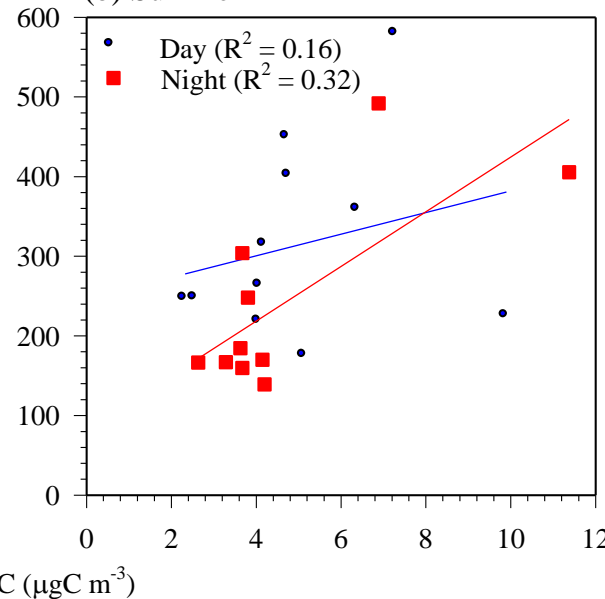

Fig. 10. Relation between water-soluble organic carbon (WSOC) and total $C_{2}-C_{4}$ diacid concentrations during (a) winter and (b) summer seasons.

analysis identifies groups of elements whose concentrations fluctuate together from one sample to another and separates these elements into "factors". Ideally, each extracted factor represents a source affecting the samples (Olmez et al., 1994; Kawamura and Sakaguchi, 1999). In the present study, factor analysis was applied to aerosol chemical composition data on 14 variables (Table 1) for all samples (both the seasons) by using statistical package SPSS version 12 (SPSS, 1988). The factor-loading matrix after "varimax" rotation is shown in Table 3. Here, "varimax" represents an orthogonal rotation criterion which maximizes the variance of the squared elements in the columns of a factor matrix. Weighting factors with an absolute value less than 0.5 were not listed in Table 3.

During the winter period the first factor comprises $50 \%$ of the total variance with high loadings of $\mathrm{C}_{2}$, ketocarboxylic acids $\left(\omega \mathrm{C}_{2}\right.$ and Pyr) and $\alpha$-dicarbonyls. The observed high correlation between these compounds suggests the formation of $\mathrm{C}_{2}$ from the oxidation of isoprene (Lim et al., 2005). In contrast, $\mathrm{C}_{3}$ to $\mathrm{C}_{9}$, maleic, fumaric and $\mathrm{Ph}$ are associated with factor' 2 , indicating they are derived from anthropogenic sources. Maleic acid is produced via ring opening of aromatic hydrocarbons such as toluene and benzene (Kawamura and Sakaguchi, 1999). Both phthalic and maleic acids are reported to be high in polluted environments (Mochida et al., 2003). In factor 3 , glyoxal and $\mathrm{tPh}$ were recognized together, suggesting an important emission from field burning of municipal wastes. Terephthalic acid is extensively produced during the burning of the municipal solid wastes and/or plastic polymers (Simoneit et al., 2005; Kawamura and Pavuluri, 2010) whereas glyoxal is produced during photo-oxidation of p-xylene as it is one of the important raw materials for terephthalic acid dimethyl ester (Volkamer et al., 2001).

In contrast, during summer, the first factor shows maximum loading of $C_{2}$ along with $C_{3}$ to $C_{6}$ diacids with lesser contributions from ketocarboxylic acids (Table 3). This factor is associated with anthropogenic emissions followed by photochemical production. The observed high correlations indicate the production of $\mathrm{C}_{2}$ from photochemical degradation of longer chain diacids (Kawamura et al., 1996b; Legrand et al., 2007). Phthalic acid and $\mathrm{C}_{9}$ were associated in second factor. This factor seems to originate from anthropogenic and biogenic sources. Pyr, Gly and MeGly also show strong correlations with this factor because their production might be enhanced by the photo-oxidation of acetylene, ethylene and isoprene contributed from anthropogenic and/or marine emissions (Warneck, 2003) and terrestrial higher plant emissions (Guenther et al., 2006). For the third factor $\mathrm{tPh}$ acid is strongly loaded, suggesting the contribution of anthropogenic emissions from burning of municipal solid wastes and/or plastic polymers.

\section{Summary and conclusions}

This study reports, for the first time, the molecular distributions of diacids, ketoacids and $\alpha$-dicarbonyls in the aerosols from the central Himalayas. Oxalic $\left(\mathrm{C}_{2}\right)$ acid was the most abundant among these species, followed by succinic $\left(\mathrm{C}_{4}\right)$, malonic $\left(\mathrm{C}_{3}\right)$ and azelaic $\left(\mathrm{C}_{9}\right)$ acids. Higher concentrations of phthalic $(\mathrm{Ph})$ acid were found in summer than winter. Higher loadings of total dicarboxylic acids, ketocarboxylic acids and $\alpha$-dicarbonyls were found to correlate with higher OC/EC ratios as compared to remote areas of the world, indicating that biomass burning is a very important source for dicarboxylic acids and related compounds in this region. Winter samples had significantly higher $\mathrm{C}_{2}$ /total diacid ratios than summer samples, indicating more fresh aerosols during summer due to atmospheric transport under favorable meteorological conditions. Glyoxal and glyoxylic acid 
are intermediates in the formation of oxalic acid for winter months. In contrast, during summer months, succinic acid can be decomposed to malonic acid and then to oxalic acid following the oxidative degradation of biogenic unsaturated fatty acids. Similar factors (variables) were obtained from the results of principal component analysis.

Higher $\mathrm{C}_{6} / \mathrm{C}_{9}$ ratios were observed for the winter season whereas $\mathrm{Ph} / \mathrm{C}_{9}$ ratios were higher during the summer season, indicating that other anthropogenic sources were more important than biomass burning in the latter season. Higher phthalic/adipic acid $\left(\mathrm{Ph} / \mathrm{C}_{6}\right)$ ratios were observed during summer than winter, indicating greater potential sources from diesel fuel vehicles than gasoline vehicles. The higher SOC/POC ratios during winter suggest an enhanced photooxidation of organics under favorable meteorological conditions with a possible development of an inversion layer and also increased photochemical production during transport of organic pollutants from source regions in the Indo-Gangetic Basin. This study suggests that the pollutants emitted from far distant sources can significantly affect the regional air quality of the Himalayas and, therefore, contribute to the effects of aerosols on climate change.

For the winter months the observation site remains above the boundary layer and represents a free tropospheric site (Hegde et al., 2009). Therefore, the observed concentrations of different organic compounds may represent the regional free tropospheric concentrations of several pollutants. On average, for the summer season, higher concentrations of several anthropogenic compounds were observed than in the winter period. Conversely, the boundary layer height increases during summer months and the observation site will be well within the boundary layer. The pollutants of northwestern Indian origin are readily transported towards the central Himalayas due to high winds, elevated temperature, and supplementary convection. Much higher concentrations of phthalic acid along with several other anthropogenic organic compounds were recorded in summer than winter. A summertime decline of oxalic acid may be associated with photochemical decomposition and dust transport over the region, a process that deserves further investigation on the trace metals such as iron that may be involved with the decomposition of oxalic acid.

Acknowledgements. This study was partly supported by the Environment Research and Technology Development Fund (B-0903) of the Ministry of Environment, Japan. We appreciate the financial support of a JSPS fellowship to PH, during which the author was on sabbatical from Indian Space Research Organisation (ISRO). The authors also thank the NOAA Air Resources Laboratory (ARL) for the provision of the HYSPLIT transport and dispersion model and/or READY website (http://www.arl.noaa.gov/ready.php) used in this publication. This paper has been read by Philip Meyers for the English corrections. We appreciate his comments.

Edited by: M. Kanakidou

\section{References}

Aggarwal, S. G. and Kawamura, K.: Molecular distributions and stable carbon isotopic compositions of dicarboxylic acids and related compounds in aerosols from Sapporo, Japan: Implications for photochemical aging during longrange atmospheric transport, J. Geophys. Res., 113, D14301, doi:10.1029/2007JD009365, 2008.

Agarwal, S., Aggarwal, S. G., Okuzawa, K., and Kawamura, K.: Size distributions of dicarboxylic acids, ketoacids, $\alpha$ dicarbonyls, sugars, WSOC, OC, EC and inorganic ions in atmospheric particles over Northern Japan: implication for long-range transport of Siberian biomass burning and East Asian polluted aerosols, Atmos. Chem. Phys., 10, 5839-5858, doi:10.5194/acp10-5839-2010, 2010.

Andreae, M. O., Atlas, E., Cachier, H., Cofer III, W. R., Harris, G. W., Helas, G., Koppmann, R., Lacaux, J.-P., and Ward, D. E.: Trace gas and aerosol emissions from savanna fires, in Biomass Burning and Global Change, edited by: Levine, J. S., 278-295, MIT Press, Cambridge, MA, USA, 1996.

Blando, J. D. and Turpin, B. J.: Secondary organic aerosol formation in cloud and fog droplets: a literature evaluation of plausibility, Atmos. Environ., 34, 1623-1632, 2000.

Cao, J. J., Wu, F., Chow, J. C., Lee, S. C., Li, Y., Chen, S. W., An, Z. S., Fung, K. K., Watson, J. G., Zhu, C. S., and Liu, S. X.: Characterization and source apportionment of atmospheric organic and elemental carbon during fall and winter of 2003 in Xi'an, China, Atmos. Chem. Phys., 5, 3127-3137, doi:10.5194/acp-53127-2005, 2005.

Chinnam, N., Dey, S., Tripathi, S. N., and Sharma, M.: Dust events in Kanpur, northern India: Chemical evidence for source and implications to radiative forcing, Geophys. Res. Lett., 33, L08803, doi:10.1029/2005GL025278, 2006.

Decesari, S., Facchini, M. C., Carbone, C., Giulianelli, L., Rinaldi, M., Finessi, E., Fuzzi, S., Marinoni, A., Cristofanelli, P., Duchi, R., Bonasoni, P., Vuillermoz, E., Cozic, J., Jaffrezo, J. L., and Laj, P.: Chemical composition of PM10 and PM1 at the highaltitude Himalayan station Nepal Climate Observatory-Pyramid (NCO-P) (5079 m a.s.1.), Atmos. Chem. Phys., 10, 4583-4596, doi:10.5194/acp-10-4583-2010, 2010.

Deguillaume, L., Leriche, M., Desboeufs, K., Mailhot, G., George, C., and Chaumerliac, N.: Transition metals in atmospheric liquid phases: Sources, reactivity, and sensitive parameters, Chem. Rev., 105, 3388-3431, 2005.

Draxler, R. R. and Rolph, G. D.: HYSPLIT (HYbrid SingleParticle Lagrangian Integrated Trajectory) Model Access via NOAA ARL READY Website: http://ready.arl.noaa.gov/ HYSPLIT.php), NOAA Air Resour. Lab., Silver Spring, MD, USA, 2010.

Dumka, U.C., Krishna Moorthy, K., Kumar, R., Hegde, P., Sagar, R., Pant, P., Singh, N., and Babu, S. S.: Characteristics of aerosol black carbon mass concentration over a high altitude location in the Central Himalayas from multi-year measurements, Atmos. Res., 96, 4, 510-521, ISSN 0169-8095, doi:10.1016/j.atmosres.2009.12.010, 2010.

Engling, G., Zhang, Y. N., Chan, C. Y., Sang, X. F., Lin, M., Ho, K. F., Li, Y. S., Lin, C. Y., and Lee, J. J.: Characterization and sources of aerosol particles over the southeastern Tibetan Plateau during the Southeast Asia biomass-burning season. Tellus B, 63, 117-128. doi:10.1111/j.1600-0889.2010.00512.x, 2011. 
Ervens, B., Feingold, G., Frost, G. J., and Kreidenweis, S. M.: A modeling study of aqueous production of dicarboxylic acids: 1 . Chemical pathways and speciated organic mass production, J. Geophys. Res., 109, D15205, doi:10.1029/2003JD004387, 2004.

Facchini, M. C., Mircea, M., Fuzzi, S., and Charlson, R. J.: Cloud albedo enhancement by surface active organic solutes in growing droplets, Nature, 401, 257-259, 1999.

Favez, O., Cachier, H., Sciare, J., Alfaro, S. C., El-Araby, T. M., Harhash, M. A., and Abdelwahab M. M.: Seasonality of major aerosol species and their transformations in Cairo megacity. Atmos. Environ., 42, 1503-1516, 2008.

Gao, S., Hegg, D. A., Hobbs, P. V., Kirchstetter, T. W., Magi, B. I., and Sadilek, M.: Water-soluble organic components in aerosols associated with savanna fires in southern Africa: Identification, evolution, and distribution, J. Geophys. Res., 108, 8491, doi:10.1029/2002JD002324, 2003.

Gautam, R., Hsu, N. C., and Lau, K. M.: Premonsoon aerosol characterization and radiative effects over the Indo-Gangetic Plains: Implications for regional climate warming, J. Geophys. Res., 115, D17208, doi:10.1029/2010JD013819, 2010.

George, S. K., Nair, P. R., Parameswaran, K., Jacob, S., and Abraham, A.: Seasonal trends in chemical composition of aerosols at a tropical coastal site of India, J. Geophys. Res., 113, D16209, doi:10.1029/2007JD009507, 2008.

Guenther, A., Karl, T., Harley, P., Wiedinmyer, C., Palmer, P. I., and Geron, C.: Estimates of global terrestrial isoprene emissions using MEGAN (Model of Emissions of Gases and Aerosols from Nature), Atmos. Chem. Phys., 6, 3181-3210, doi:10.5194/acp-63181-2006, 2006.

Hegde, P., Pant, P., Naja, M., Dumka, U. C., and Sagar, R.: South Asian dust episode in June 2006: Aerosol observations in the central Himalayas, Geophys. Res. Lett., 34, L23802, doi:10.1029/2007GL030692, 2007.

Hegde, P., Pant, P., and Kumar, Y. B.: An integrated analysis of lidar observations in association with optical properties of aerosols from a high altitude location in central Himalayas, Atmos. Sci. Lett., 10, 48-57, 2009.

Ho, K. F., Lee, S. C., Cao, J. J., Kawamura, K., Watanabe, T., Cheng, Y., and Chow, J. C.: Dicarboxylic acids, ketocarboxylic acids and dicarbonyls in the urban roadside area of Hong Kong, Atmos. Environ., 40, 3030-3040, 2006.

Ho, K. F., Cao, J. J., Lee, S. C., Kawamura, K., Zhang, R. J., Chow, J. C., and Watson, J.: Dicarboxylic acids, ketocarboxylic acids, and dicarbonyls in the urban atmosphere of China, J. Geophys. Res., 112, D22S27, doi:10.1029/2006JD008011, 2007.

Ho, K. F., Lee, S. C., Ho, S. S. H., Kawamura, K., Tachibana, E., Cheng, Y., and Zhu, T.: Dicarboxylic acids, ketocarboxylic acids, $\alpha$-dicarbonyls, fatty acids and benzoic acid in urban aerosols collected during 2006 Campaign of Air Quality Research in Beijing (CAREBeijing-2006). J. Geophys. Res., 115, D19312, doi:1029/2009JD013304, 2010.

Hopkins, R. J., Lewis, K., Desyaterik, Y., Wang, Z., Tivanski, A. V., Arnott, W. P., Laskin, A., and Gilles, M. K.: Correlations between optical, chemical, and physical properties of biomass burn aerosols, Geophys. Res. Lett., 34, L18806, doi:10.1029/2007GL030502, 2007.

Jung, J., Tsatsral, B., Kim, Y. J., and Kawamura, K.: Organic and inorganic aerosol compositions in Ulaanbaatar, Mongolia, during the cold winter of 2007 to 2008: Dicarboxylic acids, ke- tocarboxylic acids, and $\alpha$-dicarbonyls, J. Geophys. Res., 115, D22203, doi:10.1029/2010JD014339, 2010.

Kawamura, K.: Identification of $\mathrm{C}_{2}-\mathrm{C}_{10} \omega$-oxocarboxylic acids, pyruvic acid and $\mathrm{C}_{2}-\mathrm{C}_{3} \alpha$-dicarbonyls in wet precipitation and aerosol samples by capillary GC and GC-MS, Anal. Chem., 65, 3505-3511, 1993.

Kawamura, K. and Gagosian, R. B.: Implications of $\omega$ oxocarboxylic acids in the remote marine atmosphere for photooxidation of unsaturated fatty acids, Nature, 325, 330-332, 1987.

Kawamura, K. and Ikushima, K.: Seasonal changes in the distribution of dicarboxylic acids in the urban atmosphere, Environ. Sci. Technol., 27, 2227-2235, 1993.

Kawamura, K. and Kaplan, I. R.: Motor exhaust emission as a primary source of dicarboxylic acids in Los Angeles ambient air, Environ. Sci. Technol., 21, 105-110, 1987.

Kawamura, K. and Pavuluri, C. M.: New directions: Need for better understanding of plastic waste burning as inferred from high abundance of terephthalic acid in South Asian aerosols, Atmos. Environ., 44, 5320-5321, 2010.

Kawamura, K. and Sakaguchi, F.: Molecular distributions of water soluble dicarboxylic acids in marine aerosols over the Pacific Ocean including tropic, J. Geophys. Res., 104, 3501-3509, 1999.

Kawamura, K. and Yasui, O.: Diurnal changes in the distribution of dicarboxylic acids, ketocarboxylic acids and dicarbonyls in the urban Tokyo atmosphere, Atmos. Environ., 39, 1945-1960, 2005.

Kawamura, K., Kasukabe, H., and Barrie, L.: Source and reaction pathways of dicarboxylic acids, ketoacids, and dicarbonyls in Arctic aerosols: One year of observations, Atmos. Environ., 30, 1709- 1722, 1996a.

Kawamura, K., Seméré, R., Imai, Y., Fujii, Y., and Hayashi, M.: Water soluble dicarboxylic acids and related compounds in Antarctic aerosols, J. Geophys. Res., 101, 18721-18728, doi:10.1029/96JD01541, 1996b.

Kawamura, K., Umemoto, N., Mochida, M., Bertram, T., Howell, S., and Huebert, B. J.: Water-soluble dicarboxylic acids in the tropospheric aerosols collected over East Asia and western North Pacific by ACE-Asia C-130 aircraft, J. Geophys. Res., 108, 8639, doi:10.1029/2002JD003256, 2003.

Kawamura, K., Kobayashi, M., Tsubonuma, N., Mochida, M., Watanabe, T., and Lee, M.: Organic and inorganic compositions of marine aerosols from East Asia: Seasonal variations of watersoluble Dicarboxylic acids, major ions, total carbon and nitrogen, and stable $\mathrm{C}$ and $\mathrm{N}$ isotopic composition, in Geochemical Investigation in Earth and Space Science: A Tribute to Issac R. Kaplan, edited by R. J. Hill, J. Leventhal, Z. Aizenshtat, M.J. Baedecker, G. Claypool, R. Eganhouse, M. Goldhaber and K. Peters, Spec. Publ. Geochem. Soc., 9, 243-265, 2004.

Kawamura, K., Kasukabe, H., and Barrie, L. A.: Secondary formation of water soluble organic acids and $\alpha$ dicarbonyls and their contributions to total carbon and water soluble organic carbon: Photochemical aging of organic aerosols in the Arctic spring, J. Geophys. Res., 115, D21306, doi:10.1029/2010JD014299, 2010.

Kerminen, V. M.: Relative roles of secondary sulfate and organics in atmospheric cloud condensation nuclei production, J. Geophys. Res., 106, 17321-17333, 2001.

Kundu, S., Kawamura, K., Andreae, T. W., Hoffer, A., and Andreae, M. O.: Molecular distributions of dicarboxylic acids, 
ketocarboxylic acids and $\alpha$-dicarbonyls in biomass burning aerosols: Implications for photochemical production and degradation in smoke layers, Atmos. Chem. Phys., 10, 2209-2225, doi:10.5194/acp-10-2209-2010, 2010.

Lee, X., Qin, D., Jiang, G., Duan, K., and Zhou, H.: Atmospheric pollution of a remote area of Tianshan Mountain: Ice core record, J. Geophys. Res., 108, 4406, doi:10.1029/2002JD002181, 2003.

Legrand, M., Preunkert, S., Oliveira, T., Pio, C. A., Hammer, S., Gelencser, A., Kasper-Giebl, A., and Laj, P.: Origin of C2-C5 dicarboxylic acids in the European atmosphere inferred from yearround aerosol study conducted at a west-east transect, J. Geophys. Res., 112, D23S07, doi:10.1029/2006JD008019, 2007.

Lelieveld, J., Crutzen, P. J., Ramanathan, V., Andreae, M. O., Brenninkmeijer, C. A. M., Campos, T., Cass, G. R., Dickerson, R. R., Fischer, H., de Gouw, J. A., Hansel, A., Jefferson, A., Kley, D., de Laat, A. T. J., Lal, S., Lawrence, M. G., Lobert, J. M., MayolBracero, O. L., Mitra, A. P., Novakov, T., Oltmans, S. J., Prather, K. A., Reiner, T., Rodhe, H., Scheeren, H. A., Sikka, D., and Williams, J.: The Indian Ocean Experiment: widespread air pollution from South and Southeast Asia, Science, 291, 1031-1036, 2001.

Lim, H. J. and Turpin, B. J.: Origins of primary and secondary organic aerosol in Atlanta: Results of time-resolved measurements during the Atlanta supersite experiment, Environ. Sci. Technol., 36, 4489-4496, doi:10.1021/Es0206487, 2002.

Lim, H.-J., Carlton, A. G., and Turpin, B. J.: Isoprene forms secondary organic aerosol through cloud processing: Model simulations, Environ. Sci. Technol., 39, 4441-4446, 2005.

Malinowski, E. R.: Factor analysis in chemistry, (2nd edn.), WileyInterscience, ISBN 0-471-53009-3, J. Chemometr., 5, 545 pp., doi:10.1002/cem.1180050607, 1991.

Marinoni, A., Cristofanelli, P., Duchi, R., Calzolari, F., Decesari, S., Sellegri, K., Laj, P., Vuillermoz, E., Verza, G. P., and Bonasoni, P.: Aerosol mass and black carbon concentrations, a two year record at NCO-P (5079 m, Southern Himalayas), Atmos. Chem. Phys., 10, 8551-8562, doi:10.5194/acp-10-8551-2010, 2010.

Mayewski, P. A., Lyons, W. B., and Ahmad, N.: Chemical Composition of a High Altitude Fresh Snowfall in the Ladakh Himalayas, Geophys. Res. Lett. 10, 105-108, 1983.

Mayol-Bracero, O. L., Guyon, P., Graham, B., Roberts, G., Andreae, M. O., Decesari, S., Facchini, M. C., Fuzzi, S., and Artaxo, P.: Water-soluble organic compounds in biomass burning aerosols over Amazonia, 2, Apportionment of the chemical composition and importance of the polyacidic fraction, J. Geophys. Res., 107, 8091, doi:10.1029/2001JD000522, 2002.

Miyazaki, Y., Kondo, Y., Takegawa, N., Komazaki, Y., Fukuda, M., Kawamura, K., Mochida, M., Okuzawa, K., and Weber, R. J.: Time-resolved measurements of water-soluble organic carbon in Tokyo, J. Geophys. Res., 111, D23206, doi:10.1029/2006JD007125, 2006.

Miyazaki, Y., Aggarwal, S. G., Singh, K., Gupta, P. K., and Kawamura, K.: Dicarboxylic acids and water-soluble organic carbon in aerosols in New Delhi, India, in winter: Characteristics and formation processes, J. Geophys. Res., 114, D19206, doi:10.1029/2009JD011790, 2009.

Mochida, M., Kawabata, A., Kawamura, K., Hatsushika, H., and Yamazaki, K.: Seasonal variation and origins of dicarboxylic acids in the marine atmosphere over the western North Pacific, J. Geophys. Res., 108, 4193, doi:10.1029/2002JD002355, 2003.
Moorthy, K. K., Babu, S. S., Satheesh, S. K., Srinivasan, J., and Dutt, C. B. S.: Dust absorption over the "Great Indian Desert" inferred using ground-based and satellite remote sensing, J. Geophys. Res., 112, D09206, doi:10.1029/2006JD007690, 2007.

Myriokefalitakis, S., Tsigaridis, K., Mihalopoulos, N., Sciare, J., Nenes, A., Kawamura, K., Segers, A., and Kanakidou, M.: In-cloud oxalate formation in the global troposphere: a 3-D modeling study, Atmos. Chem. Phys., 11, 5761-5782, doi:10.5194/acp-11-5761-2011, 2011.

Narukawa, M., Kawamura, K., Takeuchi, N., and Nakajima, T.: Distribution of dicarboxylic acids and carbon isotopic compositions in aerosols from 1997 Indonesian forest fires, Geophys. Res. Lett., 26, 3101-3104, 1999.

Olmez, I., Beal, J. W., and Villaume, J. F.: A new approach to understanding multiple-source groundwater contamination: factor analysis and chemical mass balances, Water Res., 28, 10951101, 1994.

Padhy, P. K. and Varshney, C. K.: Isoprene emission from tropical tree species. Environ. Pollut. 135, 101-109. doi:10.1016/j.envpol.2004.10.003, 2005.

Pant, P., Hegde, P., Dumka, U. C., Sagar, R., Satheesh, S. K., Moorthy, K. K., Saha, A., and Srivastava, M. K.: Aerosol characteristics at a high-altitude location in central Himalayas: Optical properties and radiative forcing, J. Geophys. Res., 111, D17206, doi:10.1029/2005JD006768, 2006.

Pavuluri, C. M., Kawamura, K., and Swaminathan, T.: water-soluble organic carbon, dicarboxylic acids, ketoacids, and $\alpha$-dicarbonyls in the tropical Indian aerosols, J. Geophys. Res., 115, D11302, doi:10.1029/2009JD012661, 2010.

Pavuluri, C. M. and Kawamura K.: Evidence for 13-carbon enrichment in oxalic acid via iron catalyzed photolysis in aqueous phase, Geophys. Res. Lett., 39, L03802, doi:10.1029/2011GL050398, 2012.

Ram, K., Sarin, M. M. and Tripathi. S. N.: A 1 year record of carbonaceous aerosols from an urban site in the Indo Gangetic Plain: Characterization, sources, and temporal variability, J. Geophys. Res., 115, D24313, doi:10.1029/2010JD014188, 2010.

Rastogi, N. and Sarin, M. M.: Quantitative chemical composition and characteristics of aerosols over western India: One-year record of temporal variability, Atmos. Environ., 43, 3481-3488, 2009.

Rolph, G. D.: Real-time Environmental Applications and Display system (READY) Website (http://ready.arl.noaa.gov), NOAA Air Resour. Lab., Silver Spring, MD, USA, 2010.

Ruellan, S. and Cachier, H., Characterisation of fresh particulate vehicular exhausts near a Paris high flow road, Atmos. Environ., 35, 453-468, 2001.

Saarikoski, S., Timonen, H., Saarnio, K., Aurela, M., Jarvi, L., Keronen, P., Kerminen, V. M., and Hillamo, R.: Sources of organic carbon in fine particulate matter in northern European urban air, Atmos. Chem. Phys., 8, 6281-6295, 2008, http://www.atmos-chem-phys.net/8/6281/2008/.

Sagar, R, Kumar, B., Dumka, U. C., Moorthy, K. K., and Pant, P.: Characteristics of aerosol spectral optical depths over Manora Peak: A high altitude station in the central Himalayas, J. Geophys. Res., 109, D06207, doi:10.1029/2003JD003954, 2004.

Sandradewi, J., Prévôt, A. S. H., Szidat, S., Perron, N., Rami Alfarra, M., Lanz, V. A., Weingartner, E., and Baltensperger, U.: Using aerosol light absorption measurements for the quantita- 
tive determination of wood burning and Traffic emission contributions to particulate matter, Environ. Sci. Technol., 42, 33163323, 2008.

Satheesh, S. K. and Ramanathan, V.: Large differences in tropical aerosol forcing at the top of the atmosphere and Earth's surface, Nature, 405, 60-63, 2000.

Saxena, P., Hildemann, L., McMurry, P., and Seinfeld, J.: Organics alter hygroscopic behavior of atmospheric particles, J. Geophys. Res., 100, 18755-18770, 1995.

Saxena, P. and Hildemann, L. M.: Water-soluble organics in atmospheric particles: A critical review of the literature and application of thermodynamics to identify candidate compounds, J. Atmos. Chem., 24, 57-109, 1996.

Schauer, J. J., Kleeman, M. J., Cass, G. R., and Simoneit B. R. T.: Measurement of emissions from air pollution sources: 1. $\mathrm{C}_{1}$ through $\mathrm{C}_{29}$ organic compounds from meat charbroiling, Environ. Sci. Technol., 33, 1566-1577, 1999.

Sempéré, R. and Kawamura, K.: Trans-hemispheric contribution of $\mathrm{C}_{2}-\mathrm{C}_{10} \quad \alpha, \omega$-dicarboxylic acids, and related polar compounds to water-soluble organic carbon in the western Pacific aerosols in relation to photochemical oxidation reactions, Global Biogeochem. Cy., 17, 1069, doi:10.1029/2002GB001980, 2003.

Shrestha, A. B., Wake, C. P., and Dibb, J. E.: Chemical composition of aerosol and snow in the high Himalaya during the summer monsoon season, Atmos. Environ., 31, 2815-2826, 1997.

Shrestha, A. B., Wake, C. P., Dibb, J. E., Wayewski, P. A., Whitlow, S. I., Carmichael, G. R., and Ferm, M.: Seasonal Variations in Aerosol Concentrations and Compositions in the Nepal Himalaya, Atmos. Environ. 34, 3349-3363, 2000.

Shrestha, A. B., Wake, C. P., Dibb, J. E., and Whitlow, S. I.: Aerosol and precipitation chemistry at a remote Himalayan site in Nepal. Aerosol Sci. Technol., 36, 441-456, 2002.

Shrestha, P., Barros, A. P., and Khlystov, A.: Chemical composition and aerosol size distribution of the middle mountain range in the Nepal Himalayas during the 2009 pre-monsoon season, Atmos. Chem. Phys., 10, 11605-11621, doi:10.5194/acp-1011605-2010, 2010.

Simoneit, B. R. T., Medeiros, P. M., and Didyk, B. M.: Combustion products of plastics as indicators for refuse burning in the atmosphere, Environ. Sci. Technol., 39, 6961-6970, doi:10.1021/es050767x, 2005.

SPSS, Manual: Advanced Statistics Manual SPSS/PC+V 3.0, SPSS Inc., Chicago, IL, USA, 1988.

Stone, E. A., Hedman, C. J., Sheesley, R. J., Shafer, M. M., and Schauer, J. J.: Investigating the chemical nature of humic-like substances (HULIS) in North American atmospheric aerosols by liquid chromatography tandem mass spectrometry, Atmos. Environ., 43, 4205-4213, doi:10.1016/j.atmosenv.2009.05.030, 2009.

Stone, E. A., Schauer, J. J., Pradhan, B. B., Dangol, P. M., Habib, G., Venkataraman, C., and Ramanathan, V.: Characterization of emissions from South Asian biofuels and application to source apportionment of carbonaceous aerosol in the Himalayas, J. Geophys. Res., 115, D06301, doi:10.1029/2009JD011881, 2010.
Tripathi, S. N., Dey, S., Tare, V., Satheesh, S. K., Lal, S., and Venkataramani, S.: Enhanced layer of black carbon in a north Indian industrial city, Geophys. Res. Lett., 32, L12802, doi:10.1029/2005GL022564, 2005.

Turpin, B. J. and Lim, H. J.: Species contributions to $\mathrm{PM}_{2.5}$ mass concentrations: revisiting common assumptions for estimating organic mass, Aerosol Sci. Technol., 35, 602-610, 2001.

Viana, M., Maenhaut, W., ten Brink, H. M., Chi, X., Weijers, E., Querol, X., Alastuey, A., Mikuska, P., and Vecera, Z.: Comparative analysis of organic and elemental carbon concentrations in carbonaceous aerosols in three European cities, Atmos. Environ., 41, 5972-5983, 2007.

Volkamer, R., Platt, U., and Wirtz, K.: Primary and secondary glyoxal formation from aromatics: Experimental evidence for the bicycloalkylradical pathway from benzene, toluene, and p-xylene, J. Phys. Chem., A, 105, 7865-7874, doi:10.1021/jp010152w, 2001.

von Kuhlmann, R., Lawrence, M. G., Pöschl, U., and Crutzen, P. J.: Sensitivities in global scale modeling of isoprene, Atmos. Chem. Phys., 4, 1-17, doi:10.5194/acp-4-1-2004, 2004.

Wake, C. P., Dibb, J. E., Mayewski, P. A., Zhongqin, L. and Zichu, X.: The Chemical Composition of Aerosols over the Eastern Himalayas and Tibetan Plateau during Low Dust Periods, Atmos. Environ., 28, 695-704, 1994.

Wang, G., Liu, N. C., and Wang, L.: Identification of dicarboxylic acids and aldehydes of $\mathrm{PM}_{10}$ and $\mathrm{PM}_{2.5}$ aerosols in Nanjing, China, Atmos. Environ., 36, 1941-1950, 2002.

Wang, H., Kawamura, K., Ho, K. F., and Lee, S. C.: Low molecular weight dicarboxylic acids, ketoacids and dicarbonyls in the fine particles from a roadway tunnel: significant secondary production from the precursors in vehicular emissions, Environ. Sci. Technol., 40, 6255-6260, 2006a.

Wang, H., Kawamura, K., and Yamazaki, K.: Water soluble dicarboxylic acids, ketoacids and dicarbonyls in the atmospheric aerosols over the Southern Ocean and western Pacific Ocean, J. Atmos. Chem., 53, 43-61, 2006 b.

Warneck, P.: In-cloud chemistry opens pathway to the formation of oxalic acid in the marine atmosphere. Atmos. Environ., 37, 2423-2427, 2003.

Willey, J. D., Kieber, R. J., Williams, K. H., Crozier, J. S., Skrabal, S. A. and Avery, G. B., Jr.: Temporal Variability of Iron Speciation in Coastal Rainwater, J. Atmos. Chem., 37, 185-205, 2000.

Yao, X., Fang, M., and Chan, C. K.: Size distributions and formation of dicarboxylic acids in atmospheric particles. Atmos. Environ., 36, 2099-2107, 2002.

Yao, X., Fang, M., Chan, C. K., Ho, K. F., and Lee, S. C.: Characterization of dicarboxylic acids in $\mathrm{PM}_{2.5}$ in Hong Kong, Atmos. Environ., 38, 963-970, 2004.

Yu, X.-Y., Cary, R. A., and Laulainen, N. S.: Primary and secondary organic carbon downwind of Mexico City, Atmos. Chem. Phys., 9, 6793-6814, doi:10.5194/acp-9-6793-2009, 2009. 